\title{
Value of Investment: Evidence from the Oil and Gas Industry
}

Amir H. Sabet, Mahmoud Agha and Richard Heaney

University of Western Australia

\begin{abstract}
Does capital investment create wealth for oil and gas firms? Event study analysis of investment in both conventional and unconventional resources is made to answer this question. Using a sample of 1,282 acquisition and 1,503 divestiture announcements over the period 1989 to 2011 we find that resource acquisition increases equity value consistent with information asymmetry arguments while resource divestiture also increases value consistent with portfolio arguments. The technological innovation literature suggests that investment in (divestment of) technologically complex assets could result in losses (gains) relative to simpler assets. On the assumption that exploitation of unconventional resources requires more innovative technology than conventional resources, we compare returns to conventional versus unconventional but find little evidence to support this prediction. Further, we find positive total wealth effects associated with these transactions, where both buyer and seller benefiting from the transactions on average. Finally, longer term analysis of returns to buy and hold transactions shows little evidence to support market biases in reaction to acquisition or divestiture announcements.
\end{abstract}

\section{Keywords}

Market efficiency, acquisition, divestitures, conventional and unconventional oil and gas resources

\section{JEL Codes}

G31, G34, G12, G14

\section{Acknowledgments}

We thank participants at the 2012 Perth IAEE International Conference who provided comments on an earlier version of this paper. We also acknowledge the comments and suggestions of Professor Peter Hartley and members of staff in the Business School at the University of Western Australia. 


\section{Introduction}

This study investigates the impact of capital investment on the value of oil and gas firms through analysis of capital investment and divestiture decisions. These transactions, as distinct from corporate mergers or acquisitions, provide a fairly clean test of the impact of investment. Oil and gas capital investments, or divestitures, can generally be classified as belonging to one of two broad classes of resource, conventional resources or unconventional resources. This provides the opportunity to test whether technological innovation has an impact on these decisions. The technology required to exploit conventional oil and gas resources, which flow relatively freely to the surface, is less complex than that required to exploit unconventional oil and gas resources. It has been suggested that the profit derived from higher technology resources is less certain and may take longer to realize (Pástor and Veronesi 2009; Hirshleifer et al. 2013) and so these investments may be discounted by shareholders relative to the lower technology assets. Thus, the results from this study are important to furthering our understanding of the impact of investment decisions for oil and gas firms and for their industry.

The IHS Herold definitions of unconventional oil and gas resources is relied upon in this study and these align with the definitions provided by the US Department of Energy. Unconventional resources include coal-bed methane, deep-water oil and gas, heavy oil, liquefied natural gas, other non-conventional energy products ${ }^{1}$, shallow water oil and gas and tight/shale gas. ${ }^{2}$ Conventional resources are generally defined as being those reserves where

\footnotetext{
${ }^{1}$ This sub classification is created for brevity in this paper and consists of the sub categories, bitumen/oil sands, enhanced recovery, ethanol, frontier, oil shale, tight oil/shale oil and a small other sub classification which is part of the original data set.

${ }^{2}$ See Chapter 7 and associated technology assessment from the Quadrennial Review (EIA, 2015) for a detailed discussion and definition of conventional and unconventional oil and gas resources and the changes in technology that have occurred over the period of the study.
} 
the oil or natural gas flows readily to the surface in economically viable quantities. ${ }^{3}$ This simple dichotomous classification is not explained purely in terms of the age or type of the technology. For example, extracting oil from Canadian oil sands resources requires a very different technology from that applied to North Sea oil resources though both are classified as unconventional for the purposes of this study. ${ }^{4}$ Nevertheless, both of these examples involve more technological innovation than is required to exploit conventional resources. Further, The nature of technology used in the oil and gas industry has changed over time. In the early 1980's and 1990's, fracking was regarded as an unconventional technology. However, as more and more oil and gas firms employed the technological innovation in shale oil and gas production, fracking and horizontal drilling have become recognized as conventional technologies. This effect decreases the difference in technological innovation existing between conventional and unconventional resources over the period of the study. Yet, there has been considerable development of new technologies to more efficiently exploit unconventional resources leading to increasing technological complexity and a further widening in the gap in technological complexity that exists between conventional and unconventional resources (EIA, 2015). On balance, it is expected that the technological innovation required to exploit unconventional resources is greater than that required to exploit conventional resources over the period of this study. Thus, comparison of share market reaction to acquisition and divestiture of conventional and unconventional resources should provide insight into the impact of technological innovation choice on firm equity value.

\footnotetext{
${ }^{3}$ These definitions are also consistent with the Energy Information Administration classification definitions provided on their web site. See: https://www.eia.gov/tools/glossary/index.php?id=U https://www.eia.gov/tools/glossary/index.php?id=C.

${ }^{4}$ Bitumen and oil sands fall within other non-conventional sub-class within the broader unconventional resource class. North Sea oil falls within the Deep water sub class of the broader unconventional resource class.
} 
A useful approach to thinking about the impact of resource acquisition or divestiture decisions on the value of the firm draws on both portfolio theory and option pricing (Galai and Masulis 1976). Under the assumption of full information and competitive markets, it is possible to make predictions concerning the impact of both resource acquisition and divestiture on the value of the firm. There are three key steps to this approach. First, the firm's equity is modeled in terms of a call option written on the value of the portfolio of resources held by the firm. Second, individual resources earn returns that are not perfectly positively correlated with each other and so the acquisition (divestiture) of a resource by the firm decreases (increases) the volatility in returns generated by the firm's resource portfolio. Finally, if we value the firm's equity as a call option on the portfolio of resources held by the firm, then acquisition (divestiture) of a resource by the firm decreases (increases) firm value. Thus, given perfect information, a competitive market and resource returns that are not perfectly positively correlated, this simple approach predicts that announcement of resource acquisition (divestiture) decreases (increases) the value of firm equity. In particular, the prediction of increased share price on divestiture of resources supports the "focusing hypothesis", which holds that shareholders' wealth is increased when firms focus on their core business.

The problem with simple option model, as proposed here, is that the assumptions may be too restrictive. This appears to be the case for asset acquisition announcements, where information asymmetry is often observed in dealings between listed corporations and share market investors. The adoption of signaling theory has proven useful in explaining the share market reaction to a number of important corporate decisions (Myers and Majluf 1984) including asset acquisition. Essentially, given sufficient information asymmetry, the announcement of acquisition of an asset provides a costly signal to participants in the share market about the firm's plans to undertake value-enhancing investments in the future. As a 
consequence, firm value increases to reflect the value created from signaling future positive net present value investments. This effect works in the opposite direction to the negative share market reaction predicted by the option model, as described above. It should be noted that recent literature supports the signaling argument with a positive share market reaction observed on announcement of asset acquisitions (Rosenfeld 1984; Jain 1985; McConnell and Muscarella 1985; Brailsford and Yeoh 2004).

There is also support for the positive share market reaction to asset divestiture announcements predicted by the option model (Jain 1985) though more recent work suggests the possibility of a more complex story (Çolak and Whited 2006). Information asymmetry is expected to be less severe for resource divestiture than it is for resource acquisition. Given the extensive disclosures that oil and gas firms provide to the market concerning their resources, share market participants are more aware of the nature of resources that a firm might choose to divest. Thus, an increase in the share price is expected to accompany the announcement of resource divestiture consistent with the option model, with support from the empirical study by Hite et al (1987).

The nature of the oil and gas industry suggests there will also be a tendency for firms to overbid on average when acquiring oil and gas resources. This argument draws on the winners curse hypothesis, previously noted in the auction literature (Lind and Plott 1991). The winners curse arises when there is a range of parties seeking to acquire a particular resource but no single party knows the true value of the resource. While the average bid may indeed reflect the true value of the asset, in reality the bidder with the highest bid wins the contract, resulting in overpayment on average, equal to the difference between the amount paid and the true value. The magnitude of overpayment is an increasing function of the level of uncertainty about the true value of the resource. Thus, it is expected that the overpricing of 
lower technology-based conventional resources will be less pronounced than the overpricing of the higher technology-based unconventional resources. This will result in lower returns to those firms acquiring unconventional resource investments relative to those acquiring conventional resource investments. Further, those firms divesting resources will earn greater returns on announcement of sale of unconventional resources relative to conventional resources if technological innovation is sufficient to drive a wedge between these two broad resource classes.

Recent studies have focused on the question of the longer-term effect of technological innovation associated with particular investment on firm wealth. Some studies argue there is a positive relation between technological innovation and long-term stock returns (Hirshleifer et al. 2013) due to under-reaction of share price on the arrival of information (Klibanoff et al. 1998; Huberman and Regev 2001; Hirshleifer et al. 2009). While these arguments suggest market irrationality with prices reacting slowly to information, Pástor and Veronesi (2009) propose an alternative explanation which features Bayesian learning about new technology. According to their model, share prices of innovative firms initially increase following the release of good news about technological innovation. As the risk associated with the new technology switches from idiosyncratic to systematic, this results in an increase in the firm's discount rate and a subsequent decrease in its price. These theories suggest investment in technology has quite complex long-term effects on the value of the firm.

Using a sample of 1,282 acquisitions and 1,503 divestiture announcements over the period from 1989 to 2011, we find the market on average reacts positively to these investment announcements. This reaction is statistically significant for acquisition of conventional resources $(0.93 \%)$ but statistically insignificant for the acquisition of unconventional resources $(0.57 \%)$. In addition, while the share market reaction to divestiture 
of both conventional and unconventional resources is positive and significant, market reaction to divestiture of unconventional resources is significantly greater $(1.16 \%)$ than market reaction to divestiture of conventional resources $(0.79 \%)$. This is consistent with the option based explanation set out above. To further explore this effect, we run cross-sectional regressions over the full period as well as over sub-periods with separate analysis of unconventional resource sub sectors. While there is evidence of variation in coefficient sign and statistical significance for particular unconventional resource sub-sectors across the different periods, there is some support for the univariate results. Furthermore, there is evidence of a positive total wealth effect on announcement of acquisition of conventional and unconventional resources. On average, the total wealth effect of acquisition and divestiture of conventional resources is $1.3 \%$. Interestingly, there is evidence of greater wealth effect being captured by small firms in these deals.

Finally, we create portfolios of oil and gas firms based on the nature of the acquisition: Conventional, Unconventional and MIX. Analyses of long-term and short-term portfolio returns show no significant difference in the returns to invest in either conventional or unconventional resource portfolios. While this is inconsistent with the findings of Hirshleifer et al. (2013), it suggests that investors quickly and fully impound the information concerning oil and gas firm capital investment decisions into stock prices, which is consistent with market efficiency.

This study is organised as follows. Section 2 gives a brief overview of the literature and the hypotheses to be tested in this analysis. Data used are described in section 3 and methodology and empirical design are explained in section 4 . In section 5 we report and discuss the empirical results, whilst section 6 concludes. 


\section{Hypotheses}

Advances in technology can have a profound impact on the value of firms in the oil and gas industry. For example, one recent advance, the development of fracking, led to increased supply of natural gas (Joskow 2013) and a subsequent decrease in natural gas prices (See Figure 1). Technological innovations have expanded world energy resources, increasing the quantity of energy supplies and helping to maintain economic growth. For example, the U.S. Energy Information Administration (EIA) found that production of dry shale gas, one of the major unconventional oil and gas resources, increased 23\% in the past 10 years (EIA 2011c).

\section{(Insert Figure 1 about here)}

Figure 1 illustrates the importance of technological change in explaining the movement in natural gas prices. It should be noted that the quantity of horizontal drilling has increased substantially over the past few years with a consequent fall in oil and gas prices. These technological changes have received considerable attention from policy makers and investors and this is reflected in the level of news published in the Wall Street Journal concerning unconventional resources over the period from 2005 to 2011 (See Figure 2). ${ }^{5}$

(Insert Figure 2 about here)

While this study is not about corporate mergers and acquisitions, we rely on the mergers, acquisition and capital expenditure literature to develop some of the hypotheses set out in the following sub-sections.

\footnotetext{
${ }^{5}$ The reliability and importance of information published in the Wall Street Journal are noted in the literature (Mitchell \& Mulherin 1994; Tetlock 2007) and the level of media attention received by unconventional resources highlights the importance of these resources for investors.
} 


\subsection{Acquisition}

Consistent with the signaling hypothesis, previous studies find a positive market response to capital acquisition announcements (Rosenfeld 1984; Jain 1985; McConnell and Muscarella 1985; Brailsford and Yeoh 2004). According to this hypothesis, acquisition of conventional resources and unconventional resources signal to the market information about the future prospects of the firm. While a positive market response to capital acquisition is expected, this study sheds further light on the share market reaction to announcements of acquisitions of unconventional resources relative to share market reaction to acquisitions of conventional resources. The distinction in market reaction further highlights the impact of individual firm investment announcements on share prices. Much of the published research on this issue implies that the impact on share price will vary with the type of investment and the signal conveyed. As, Brailsford and Yeoh state, “... investment information should not be seen in absolute terms; rather, it is context specific" (Brailsford and Yeoh 2004, Page 223).

Four theories are proposed to explain the variation in market reaction to acquisition of unconventional resources relative to conventional resources. According to the under-reaction theory (Hirshleifer et al. 2013) and the winners curse (Lind and Plott 1991) theory, share market reaction to the acquisition of unconventional resources is expected to be less than the share market reaction to acquisition of conventional resources. Similarly, under the option model, while resource acquisition is predicted to decrease share value on average, it is assumed that returns to unconventional resources are less correlated with equity returns than returns to conventional resources. This will result in acquisition of unconventional resources having a more negative impact on share value than acquisition of conventional resources. Finally, Pástor and Veronesi (2009) argue that the share price of innovative firms initially increases as a result of good news about technological innovation. As the risk associated with technological innovation switches from idiosyncratic to systematic this results in an increase 
in the firm's discount rate and a decrease in its stock price. Accordingly, we posit the following hypotheses:

H1A: The share market reaction to announcements of acquisition of conventional resources is positive and significant.

H1B: The share market reaction to announcements of acquisition of unconventional resources is positive and significant.

H1C: The share market reaction to acquisition of unconventional resources is less than the share market reaction to acquisition of conventional resources.

The option model predicts a negative share market reaction to resource acquisition where the returns to the resource are not perfectly correlated with the return to the portfolio of resources held by the firm. This provides alternative hypotheses for both H1A and H1B though this model supports hypothesis H1C.

\subsection{Divestiture}

According to the option model described above, announcement of divestiture will result in an increase in the equity value of the divesting firm. Assume the returns to the divested resource are not perfectly positively correlated with the returns to the remaining resources of the firm. On divestiture of the resource, the value of the equity in the remaining resources increases with the subsequent increase in the volatility of returns accruing to these remaining resources (Galai and Masulis 1976). Further, if unconventional resources were more weakly correlated with the remaining resources held by the firm than conventional resources, then the increase in equity value from divesting unconventional resources would be greater than the increase in 
equity value from divesting conventional resources. ${ }^{6}$ This gives rise to the following hypotheses:

H2A: The share market reaction to announcements of divestiture of conventional resources is positive and significant.

H2B: The share market reaction to announcements of divestiture of unconventional resources is positive and significant.

H2C: The share market reaction to divestiture of unconventional resources is greater than the share market reaction to divestiture of conventional resources.

\subsection{Synergy effects}

While this paper is not concerned with corporate merger or acquisition among firms within the oil and gas industry, we do draw on this literature in developing the third hypothesis. Various explanations have been noted in the literature concerning whether merger or acquisition activity creates wealth for the two parties to a merger or acquisition transaction. This question is generally tested by summing the change in value of the acquirer and the change in value of the seller around the time of the announcement of the acquisition. If this sum is positive then the transaction is said to create wealth. If this sum is negative then the transaction is said to destroy wealth.

The first explanation for wealth creation, commonly noted in the takeover literature, concerns synergy theory (Halpern 1983). If synergies are created on acquisition of the asset then the change in the combined share market value of the acquiring and divesting firms is positive and significant (Bradley et al. 1988; Kaplan and Weisbach 1992). The second

\footnotetext{
${ }^{6} \mathrm{We}$ are not able to assess whether this correlation is indeed lower for unconventional oil and gas resources. Return data for specific oil and gas resources are not available for analysis due to the nature of this market and so correlations cannot be calculated between the returns earned on an oil and gas firm investment and those earned on specific oil and gas resources.
} 
explanation concerns non-synergistic theories of mergers and acquisitions. These include managerial hubris (Roll 1986), managerial entrenchment and empire building (Jensen 1986; Shleifer and Vishny 1989). These alternative theories predict a non-positive combined share market reaction. Recent empirical tests are whole-of-market studies, which generally include the petroleum industry as part of the sample (Mulherin and Boone 2000; Jain et al. 2011). These studies suggest there is a wealth creation from merger and acquisition transactions on average, though there is evidence of considerable wealth destruction for some sub-sectors of the market (Harford, Humphery-Jenner, Powell, 2012).

Behavioral explanations provide the third set of explanations and include market timing and momentum trading. These behavioral explanations suggest that merger and acquisition transactions are driven by price levels or perhaps by past merger or acquisition activity. If these explanations apply then there is little reason to expect merger or acquisition transactions to create wealth on average. In a study of Canadian oil and gas firms, $\mathrm{Ng}$ and Donker (2013) find firms take into account both oil and gas prices and individual firm oil and gas reserves when choosing to merge with, or acquire, another oil and gas firm. Hsu and Zhu (2017) add to this literature using a more recent sample of US oil and gas firms. While they include prices to proxy for the value of reserves, consistent with $\mathrm{Ng}$ and Donker (2013), they also include production growth as a proxy both for technological advances and recoverable reserves. Both of these variables are found to explain changes in merger and acquisition activity over the period of their study. They also find some support for momentum effects using lagged merger and acquisition activity. More relevant to the present study is the $\mathrm{Ng}$ and Donker (2013) finding that oil and gas acquirer firm value decreases on average on announcement of an acquisition while oil and gas target firm value increases around this time. It is not possible to determine whether total wealth was actually created by the transactions analysed in this study. 
Given the nature of oil and gas firms and the simpler nature of resource acquisition or divestiture transactions, it is expected that information asymmetry theory and the option model will drive the share market reaction on announcement of these transactions. In this case, wealth creation occurs where the information asymmetry effect exceeds the option model effect for the acquiring firm. Wealth destruction occurs where information asymmetry is immaterial for the acquiring firm and the remaining option model effects are such that the decrease in value of the acquiring firm exceeds the increase in value of the divesting firm. Given this argument and the references to the earlier merger and acquisition literature, we expect the oil and gas resource based transactions to result in creation of valuable synergies on average and this gives rise to the following hypotheses.

H3A: The combined wealth effect for matched acquisition and divestiture of conventional resources is positive.

H3B: The combined wealth effect for matched acquisition and divestiture of unconventional resources is positive.

\subsection{Portfolio analysis}

In this sub-section, we investigate the market reaction to acquisition announcements for a portfolio of firms, which only invest in either conventional resources or unconventional resources. According to the under-reaction hypothesis, the immediate market reaction to announcement of acquisition of an innovative asset is uncertain (Hirshleifer et al. 2013), but there is a positive relation between innovation and firm future stock returns (Hirshleifer et al. 2013). Applying this notion to unconventional resources and conventional resources, the immediate (short-term) market reaction to acquisition of a unconventional resource is expected to be less than that observed for acquisition of conventional resources. Unconventional resources are new to the market and it is argued that investors encounter 
difficulty in analysing the economic implications of the acquisition of these resources in the short run. This is consistent with market irrationality noted previously in the literature review. As such, the market tends to undervalue the unconventional resources on announcement of their acquisition. Yet, the market is expected to react positively to these announcements in the long run, consistent with the positive relation observed in the literature between innovative asset acquisition and the future stock returns. Indeed, Hirshleifer et al. (2013) argue that inefficient markets and limited investor attention result in share prices that do not fully reflect new information. In particular, the market is expected to underreact to information in the short run when such information is less salient or arrives during period when investors are less attentive (Klibanoff et al. 1998; Huberman and Regev 2001; Hirshleifer et al. 2009).

An alternative explanation for the discount of the value of unconventional resources relative to conventional resources can be attributed to information asymmetry between the seller and the acquirer of the resource. According to this theory, the acquirers know less about unconventional resources on acquisition date than they know about conventional resources. Given the greater information asymmetry concerning unconventional resources, these resources will tend to be written down more than conventional resources, all else held constant, on announcement of acquisition. The lower share price reaction of a firm that acquires unconventional, rather than conventional resources, will ensure subsequent greater long-run returns as the market eventually recognises the value of these investments. Thus:

H4: The long-term return for a portfolio of firms following announcement of acquisition of conventional resources is expected to be less than the long-term return for a portfolio of firms following announcement of acquisition of unconventional resources. 


\section{Data sources and sample selection}

Capital expenditure announcements are extracted mainly from news wire services. The Wall Street Journal Index (McConnell and Muscarella 1985; Borna and Ryan 2000), the Dow Jones News Retrieval (Vogt 1997) and the Lexis Nexis News Wire (Chung et al. 1998; Kim 1998) are used to obtain information on capital expenditure announcements by U.S. listed firms. Some studies obtain information on asset level acquisitions from the Securities Data Corporation (SDC) database. For example, Bates (2005), Çolak and Whited (2007) and Warusawitharana (2008) use SDC database in their study of asset purchases and divestitures and Akhigbe, Martin and Whyte (2007) use SDC in their study of partial acquisitions of target firms.

While the Securities Data Corporation (SDC) database is well regarded in the literature as a primary database for merger and acquisition type studies (Raghavendra Rau and Vermaelen 1998; Rossi and Volpin 2004), Herold database is commonly used in the energy finance literature (Merton and Upton 1985). The Herold database contains detailed information on acquisition and divestiture in the energy sector, ranging from individual assets (capital investments) to corporate mergers and acquisitions. ${ }^{7}$ This study is based on capital investment data obtained from the Herold merger and acquisition database with the majority of the transactions referring to acquisition or divestiture of upstream resources. These transactions are identified via firm investment announcements, SEC filings and news releases in the media, consistent with other capital expenditure studies, which generally rely on news wire services. A key point of difference with the Herold data is the extensive coverage of the

\footnotetext{
${ }^{7}$ Herold data have also been extensively used in finance studies over the past 30 years. Examples of this include using financial and operational data for valuation of reserves and oil and gas firms (Merton \& Upton 1985; Harris \& Ohlson 1987; Boone 1998), analysing political risk using Herold Merger and Acquisition data (Click \& Weiner 2010), examining the relation between Herold estimates and stock prices (Magliolo 1986), investigating the role of historical cost to value oil and gas firms (Ghicas \& Pastena 1989) and analysing investment behaviour of oil and gas firms (Mohn \& Misund 2009, 2011)
} 
more unique features of firms in the oil and gas industry. For example, Herold provides extensive sector and subsector classification schemes on which we rely in this analysis. ${ }^{8}$

Financial data used to calculate control variables are extracted from CRSP and Compustat. The four-factor asset pricing model factors, used in estimation of abnormal returns, are obtained from Kenneth French's webpage. ${ }^{9}$ Volatility estimates for crude oil and natural gas are calculated using the CME Group crude oil (WTI) and natural gas (Henry Hub) futures contracts respectively. These estimates are calculated using the last 30 daily futures returns for the contract that ceases trading just prior to the month of the announcement.

An initial sample of 33,542 transactions was obtained from the Herold merger and acquisition database covering the period 1989 to Aug 2011. This includes all energy related asset and corporate acquisitions worldwide. Several filters are applied to constrain the sample to U.S. firm capital investments or divestitures, specifically excluding corporate mergers or acquisitions. The final sample of asset acquisition sectors is initially restricted to four sectors, upstream, midstream, downstream and oilfield services. There are 8,236 deals remaining after excluding firms with no financial data in the CRSP and the Compustat merged database. Deals that are not also reported on SDC platinum or the news wire services are also excluded. Observations with simultaneous announcement of acquisition of conventional and unconventional assets by the same firm on the same date are excluded from the sample. Finally, takeover announcements are excluded from the capital expenditure announcements to maintain a clean sample that focuses on capital expenditure transactions (Brailsford and Yeoh 2004). This leaves a final sample of 1,282 acquisition and 1,510 divestiture deals after excluding firms with insufficient share price data during the event window and estimation period or firms with insufficient oil and gas operational data (See Table 1).

\footnotetext{
${ }^{8}$ For example, Herold provides information on all asset acquisition deals in the oil and gas industry in upstream, midstream, downstream and oilfield services.

${ }^{9}$ Kenneth French Webpage (http://mba.tuck.dartmouth.edu/pages/faculty/ken.french/data_library.html).
} 
(Insert Table 1 about here)

Descriptive statistics are reported in Table 2. Panels A and B report the statistics for the control variables in the acquisition and divestiture sample respectively. The choice of the control variables is consistent with previous studies (Sicherman and Pettway 1992; Mulherin and Boone 2000; Moeller et al. 2004). Vol-Oil and Vol-Gas refer to volatility estimates calculated for the CME Group crude oil (WTI) and natural gas (Henry Hub) futures contracts respectively. These volatility estimates are calculated using the last 30 daily futures returns for the contract that ceases trading in the month immediately preceding the announcement month. Total assets for the firm (AT) are expressed in millions, with the (Size) control variable used in regression analysis being the natural log of total assets. Consistent with Uysal (2011), the market-to-book ratio is used to control for growth; it is calculated as the sum of the market value of equity plus preferred stock plus liabilities minus balance sheet deferred taxes and investment tax credit scaled by book value of total assets (AT). Return on assets (ROA) is the ratio of earnings before interest and taxes (EBIT) to total assets. Leverage, calculated as total liabilities to total assets, is used as a control variable. Firm age (Age) is the natural log of the number of years the firm has been listed on the stock exchange (AA) (See Appendix A for a description of variables).

(Insert Table 2 about here)

The average size of the firms in the acquisition sample is less than the average size of the firms in the divestiture sample. Further, the average firm age in the divestiture sample is 5 years older than the average firm age in the acquisition sample. Firms in the acquisition and divestiture groups have, on average, a ROA of $15 \%$ per annum. Firms in the acquisition group tend to have a higher market-to-book ratio (growth), lower leverage and are younger although these mean differences are not economically large. The oil and the natural gas 
volatility measures tend to be higher for the acquisition sample than for the divestiture sample, possibly reflecting differences in the timing of the announcements included in these two sub-samples.

Spearman rank correlation coefficients are reported for the acquisition and divestiture sub-samples in Panels A and B of Table 3. In both panels, the correlation coefficients show that older firms tend to be larger and have greater ROA regardless of whether they choose to acquire or divest assets. Yet, while larger firms have lower market-to-book ratio and higher leverage in the acquisition sample, the market-to-book ratio is higher for the divestiture group with no link between age and leverage evident for this group. We explore the differences between these two groups in the analysis reported below.

\section{(Insert Table 3 about here)}

Panel A of Table 4 reports the frequency and the proportion of acquisition and divestiture announcements that fall within the classifications, conventional and unconventional. Announcements falling under the unconventional classification are further sorted into seven sub classifications. There are 737 announcements of acquisition of conventional resources and 545 announcements of acquisition of unconventional resources. For divestitures, a total of 918 announcements related to conventional resources and 585 announcements related to unconventional resources. There are somewhat more divestiture announcements than acquisition announcements, with around $60 \%$ of the announcements falling within the conventional classification. Further, deepwater and shallow-water announcements account for most of unconventional acquisition and divestiture announcements. Panel B of Table 4 further dissects each of these announcements into one of four further classifications: downstream, midstream, oil field and upstream. The majority of the announcements are classified as upstream (91\% for acquisitions and $92 \%$ for 
divestitures). The annual acquisitions and divestitures frequencies are reported in Table 5. These suggest a general increase in the number of announcements over the study period.

(Insert Tables 4 and 5 about here)

\section{Empirical Design}

\subsection{Univariate analysis}

We use the event study method (Ball and Brown 1968; Fama et al. 1969) to assess the impact of capital expenditure announcements on oil and gas firm share price. As capital expenditure announcements tend to be randomly distributed over time, we use the traditional event study approach. Both observed return and expected return are required to estimate the abnormal return for day $t$ within the event window for announcement (event) $i$ drawn from the $N$ events that make up the announcement sample. Coefficients used in the calculation of expected returns are estimated over a 258-day estimation period starting from day $t=-269$ to day $t=-11$. The announcement date is allocated the event time of zero, $t=0$, and the event windows considered in this analysis range from day $t=-10$ to day $t=+10$. The abnormal return for each day $t$ in an event window is calculated by subtracting the expected return from the observed return on that day as follows:

$A R_{i t}=R_{i t}-E\left(R_{i t}\right)$

Where, $A R_{i t}$ represents the abnormal return at day $t$ for event $i, R_{i t}$ denotes the observed return at day $t$ for event $i$ and $E\left(R_{i t}\right)$ is the expected return at day $t$ for event $i$ calculated using the coefficients estimated over the estimation period using ordinary least squares regression. Abnormal returns are estimated using numerous models in the literature, though the Carhart four-factor model is generally relied upon in this study. This model, incorporates the three Fama and French factors (Fama and French 1992) as well as Carhart 
momentum factor (Carhart 1997). Given this model, the expected return estimate at day $t$ for event $i$ is calculated as follows:

$$
E\left(R_{i t}\right)=\hat{\alpha}_{i}+\hat{\beta}_{i} R_{M, t}+\hat{s}_{i} S M B_{t}+\hat{h}_{i} H M L_{t}+\hat{u}_{i} U M D_{t}
$$

Where, $E\left(R_{i t}\right)$ represents the expected stock return on day $t$ for firm associated with event $i, R_{M, t}$ denotes the return of the value weighted CRSP market index at day $t, S M B_{t}$ refers to the return of the small minus big portfolio at day $t$, which is a proxy for the size effect, $H M L_{t}$ denotes the return of the high minus low book-to-market ratio firm portfolio at day $t$, which captures the value/growth effect and $U M D_{t}$ represents the returns of high minus low portfolio at day $t$, which captures the momentum effect.

As a robustness check, the market model and the zero-one model are also used to estimate expected returns. The market model is a one-factor market model based on the return of the value weighted CRSP share market index. A constrained form of this model, the zero-one market model, is also used in the analysis. ${ }^{10}$ In this case the abnormal return is calculated by subtracting the value weighted CRSP share market return from the firm's observed return. This constrained form of the market model has also been used previously in the literature as a robustness check (Moeller et al. 2004).

For each event $i$, the cumulative abnormal return (CAR) is calculated for eight different windows CAR is calculated as follows:

$C A R_{i, m, n}=\sum_{t=m}^{t=n} A R_{i, t}$

Where the interval $(m, n)$ refers to one of the following windows:

\footnotetext{
${ }^{10}$ This measure of expected return imposes a zero intercept and a beta of one on the simple one factor market model.
} 
$(-10,+10),(-5,+5),(-5,+1),(0,0),(-1,+1),(0,+1),(-1,+5),(+1,+10)$

The event window interval $(m, n)$ refers to a particular sub-period which surrounds the announcement date (event day $t=0$ ). If the announcement date is accurately identified then it might be sufficient for the estimated cumulative abnormal return period to focus on the days immediately surrounding the announcement date such as $(0,0),(-1,+1)$ or $(0,+1)$. If there is some uncertainty about the accuracy of the announcement date then a longer sub-period might be required to capture the impact of the announcement on the firm's share price. Sub-periods, $(-10,+10)$ or $(-5,+5)$ are included in analysis to allow for this possibility. Finally, sub-period $(-5,+1)$ is included to allow for the possibility of information leakage in the market prior to announcement and sub-periods $(-1,+5)$ and $(+1,+10)$ are included to allow for the possibility of market inefficiency, where the market might be slow to react to the announcement. The 3-day CAR estimated three days around the announcement date $(-1,+1)$ for each event $i$ will be used in the regression analysis.

For the univariate analysis, we calculate the average CAR (or CAAR) for each of the above windows $(m, n)$ in order to analyse the significance of the abnormal return. Average CAR for $N$ events is calculated as follows:

$$
C_{A A R_{m, n}}=\frac{1}{N} \sum_{i=1}^{N} C A R_{i, m, n}
$$

The literature provides a range of parametric and non-parametric methods that could be used to test the statistical significance of abnormal returns and cumulative abnormal returns calculated for the various event windows. Two problems of particular note have been identified in the recent literature, event induced volatility and cross correlation in abnormal returns. While a number of methods have been proposed to deal with these (Kolari and 
Pynnönen 2010), we use the Boehmer et al. (1991) standardized t-test in this study to assess the importance of these issues for our sample.

In addition to analysis of short-term effects, we also report the results from analysis of the longer-term impact of acquisition and divestiture decisions on share returns. We calculate Buy and Hold Abnormal Returns (BHR or BHAR) for stock portfolios in an effort to identify the long-term impact of these decisions. Two different approaches are used. In the first approach (BHR), buy and hold return is calculated over a holding period $T$ following the announcement date $(t=0)$ as follows:

$B H R_{0, T}=\prod_{t=0}^{T}\left(1+R_{i, t}\right)-1$

The second approach (BHAR) follows Fu et al. (2013) who use a market adjusted buy and hold return which is calculated as:

$\operatorname{BHAR}_{0, T}=\left(\prod_{t=0}^{T}\left(1+R_{i, t}\right)-1\right)-\left(\prod_{t=0}^{T}\left(1+R_{m, t}\right)-1\right)$

Where $R_{i, t}$ is the monthly stock return for security $i$ during month $t ; R_{m, t}$ is the monthly return for the CRSP value weighted market index during month $t$ and $T$ refers to the holding period. Three holding periods of 12, 24 and 36 months are used in the calculation of these returns. These returns are then averaged to check if there is a significant long-term impact post acquisition events.

\subsection{Analysis of wealth effect}

We estimate the combined wealth effect for the acquirer and seller in each transaction using both equally weighted cumulative abnormal returns (EWCAR) and the value weighted cumulative abnormal returns (VWCAR). The value weighted cumulative abnormal return 
calculation follows the procedure set out by Mulheim and Boone (2000). While Mulherim and Boone (2000) use only the zero-one version of the market model to estimate expected returns in their analysis, we estimate the value weighted cumulative abnormal return using the Carhart four factor model (Carhart 1997). ${ }^{11}$ Consistent with Mulheim and Boone (2000), we use the 3-day CAR $(-1,+1)$ to estimate the value weighted CAR for each event $i$ using the matched acquirer and seller as follows:

$V W C A R=\frac{\left(C A R_{A c q} \times W A C Q_{t-2}+C A R_{D I V} \times W D I V_{t-2}\right)}{W A C Q_{t-2}+W D I V_{t-2}}$

Where $C A R_{A c q}$ refers to the acquirer firm's cumulative abnormal return using the 3 days around the announcement day. $W A C Q_{t-2}$ is the equity value of the acquirer firm two days prior to the announcement date. $C A R_{D I V}$ corresponds to the divestiture firm's cumulative abnormal return using the 3 days around the announcement day. $W D_{i-2}$ is the equity value of the divestiture firm two days prior to the announcement date. The combined returns for matched pairs are then averaged to check if there is a significant total wealth effect.

\section{Empirical results}

In this study, we investigate the sensitivity of the oil and gas firm value to announcement of acquisition or divestiture of resources. Further, we test for the impact of technological innovation on oil and gas firm share by comparing the market reaction associated with announcements concerning higher technological innovation unconventional resources with announcements concerning the conventional resources, which require less technological innovation. Further, the total wealth effect of acquisition and divestiture for the firms involved in a transaction is also investigated. Finally, the share price sensitivity of oil and gas

\footnotetext{
${ }^{11}$ For robustness, we also estimate the expected returns for CAR calculation using the zero-one model and the market model. There is little difference in the results and so we do not report them separately here.
} 
firm investment in various subsectors of oil and gas industry is explored. The results reported here are based on abnormal returns calculated using the four-factor model. ${ }^{12}$

\subsection{Acquisition of conventional and unconventional resources}

Univariate analysis is initially used to investigate the share market reaction to announcements of acquisition and divestiture of unconventional resources and conventional resources. We compare the market reaction to these announcements in further exploring the impact of technological innovation on the value of oil and gas firms.

Table 6 reports event study results for separate acquisition and divestiture samples. Panel A of Table 6 reports the event study results for acquisition of conventional and unconventional resources. Consistent with hypothesis $H 1 A$, there is a positive and significant market reaction to acquisition of conventional resources. This is supported for each event window that includes the announcement day (Panel A). The results for announcements of acquisition of unconventional resources are less well supported. While the coefficients are positive for event windows including the announcement day, statistical significance is only found for the event window $(0,0)$. This announcement day result supports hypothesis $H 1 B$, but is not particularly convincing given the statistical significance of this result is so sensitive to event window choice.

(Insert Table 6 about here)

Unconventional resource acquirers also realize lower returns than conventional resource acquirers on average over event windows spanning the announcement day. However, it should be noted that this difference is not statistically significant, with the exception of the average CAR for event window $(-5,+1)$. The average return for conventional

\footnotetext{
${ }^{12}$ Given the consistency of the results observed across the three models used to estimate expected returns, we focus on the abnormal returns derived using the four-factor model in the following subsections.
} 
resources for the three days around the announcement is $0.93 \%$ and for unconventional resources it is $0.57 \%$. Thus, while the abnormal return on announcement of unconventional resource acquisition is less than abnormal return on announcement of conventional resource acquisition there is little statistical support for hypothesis $H I C$, except for the event window $(-5,+1)$

The positive and significant share market response to the announcement of the acquisition of conventional resources is consistent with previous capital acquisition studies (Rosenfeld 1984; Jain 1985; Hite et al. 1987). Yet, a positive and statistically insignificant market response is also noted in some studies (Zaima and Hearth 1985; Sicherman and Pettway 1987; Datta and E. Iskandar-Datta 1995). We find a similar result here with respect to the announcement of acquisition of unconventional resources. Thus, one contribution of this study is to highlight the variation in market response to announcement of acquisition of conventional resources compared with unconventional resources. To the best of our knowledge, this is the first study which documents differential share market reaction to these two broad classes of capital investment (acquisition) announcements for firms in the oil and gas industry.

In Panel B of Table 6 we find support for hypotheses H2A and H2B and the notion that the market reacts positively to the announcement of firms divesting resources, whether conventional or unconventional resources. While the share market response on announcement of acquisition of unconventional resources is only positive and significant for the event window $(0,0)$, there is a positive and statistically significant market response to announcement of divestiture of these resources for all event windows that include the announcement date (See Panel B of Table 6 for divestiture results). Of particular interest is the market response for the three-day period around the announcement, which is positive and 
statistically significant for the divestiture of both conventional $(0.79 \%)$ and unconventional resources $(1.16 \%)$. Further, the share market reaction to divestiture of unconventional resources is generally greater than the market reaction to divestiture of conventional resources and, while this difference is economically significant $(0.37 \%$ or $4.5 \%$ per annum respectively), it is not statistically significant for any of the event windows reported in Panel B. Hence, hypothesis $\mathrm{H} 2 \mathrm{C}$ is not supported.

\subsection{Wealth effect and conventional and unconventional resources}

In this subsection we investigate the combined wealth effect of resource acquisition and divestiture by focusing on the share market reaction to the announcement of a resource transaction with respect to both the buyer and the seller. ${ }^{13}$ Previous studies find a positive wealth effect for single industry sectors following the announcement of acquisition and divestiture (Kaplan and Weisbach 1992; Mulherin and Boone 2000). In this study, we examine the combined wealth effect for conventional and for unconventional resources separately. For every acquisition there is a matching divestiture and the following analysis focuses on these matched acquisition/divestiture pairs for which there is a complete set of data available for analysis. Combined wealth effects are calculated for the matched acquisition and divestiture pairs using both equal weighting (EV) and value weighting (VW).

Table 7 reports the combined wealth effects for the matched acquisition and divestiture pairs. For the sample of 172 conventional resource matched acquisition and divestiture pairs, the average equally-weighted 3-day CAR is $1.33 \%$ and the average value weighted 3-day CAR is $0.56 \%$. These findings suggest that the transfer of a conventional resource from one oil and gas firm to another, through separate purchase and sale transactions, creates wealth on average. This supports the existence of a synergy effect for our sub-sample of matched

\footnotetext{
${ }^{13}$ Paired acquisition and divestiture announcement analysis relies on matched samples where data is available for both the acquirer and the seller.
} 
acquirer/divestiture oil and gas firm pairs for conventional resources. This supports hypothesis $\mathrm{H} 3 \mathrm{~A}$.

For the unconventional resource sub-sample of 141 matched acquisition and divestiture pairs, the average equally weighted 3-day CAR of $1.62 \%$ is positive and higher than that of conventional resources $(1.33 \%)$. This result supports hypothesis $H 3 B$. Similarly, the average value weighted 3-day CAR of $0.61 \%$ is higher than that of conventional resources $(0.56 \%)$ though this is not statistically significantly different from zero.

(Insert Table 7 about here)

The variation between equal weighted and value weighted unconventional resource results highlights the importance of the relative size of the buyers and sellers in analysis of the matched buyer/seller pairs. The variation in cumulative abnormal returns suggests the benefits of these transactions are not evenly spread across the buyer and seller in each pair. Indeed, these results suggest that more of the created wealth is attributed to the smaller of the two firms on average. In summary, these results support hypotheses H3A and H3B for equally weighted pairs though only the conventional resource finds support with the value weighted pairs based analysis. Finally, while somewhat smaller in magnitude, the positive wealth effect reported in this study is also consistent with the results reported by Mulherin and Boone (2000).

\subsection{Cross sectional analysis of market reaction to acquisition announcement.}

Cross sectional analysis is conducted to explore the variation in share market reaction to acquisition or divestiture of conventional or unconventional resources. Statistical tests are calculated using robust standard errors adjusted for clustering at the firm level. The dependent variable is the 3-day CAR estimated using the Carhart four-factor model and the variables of interest are indicator variables used to identify the various unconventional 
resource subsectors. Consistent with previous studies, control variables are also included. These include estimates of crude oil and natural gas return volatility (Grullon et al. 2012), Size (Moeller et al. 2004), growth (Kerstein and Kim 1995), ROA (Hirshleifer et al. 2013), leverage (Haushalter et al. 2002) and age (Hobijn and Jovanovic 2001).

\subsubsection{Acquisitions}

Table 8 reports the regression results for the acquisition sample over the whole sample period 1989-2011. In the second column of Table 8, the indicator variable of interest is TECHDA, which identifies unconventional resource based investments as a group. The statistically insignificant positive coefficient for TECHDA suggests that on average the share market reaction to acquisition of unconventional resources is not significantly different from the share market response to acquisition of conventional resources. This is consistent with the results from univariate analysis and does not support hypothesis $H 1 C$. Further, the generally positive and statistically significant constant coefficient supports Hypothesis $H 1 A$ concerning conventional resource acquisitions and is consistent with the results reported in Panel A of Table 6.

(Insert Table 8 about here)

Further, we investigate the share market reaction to acquisition of the different subsectors that make up the unconventional resource classification. These include coal bed methane, deep water, heavy oil, liquefied natural gas, shallow water, shale gas/tight gas and other unconventional resources. ${ }^{14}$ An indicator variable is included for each unconventional resource subsector. The coefficient for each indicator variable captures the share market reaction to acquisition of the particular type of unconventional resource relative to

\footnotetext{
${ }^{14}$ Herold identifies a wider range of classifications than reported here. To aid analysis, the less numerous classifications are combined into the "other non-conventional" classification reported here.
} 
conventional resources. The third column in Table 8 reports the market reaction to these various unconventional resource subsectors. The results suggest that there is little significant difference in market reaction to the various subsectors of unconventional resources relative to conventional resources. This more detailed test also fails to support hypothesis $H 1 C$.

So far, we have examined the share market reaction to various subsectors of the unconventional resource classification for the full sample period from 1989 to 2011. Within this time period, the landscape of the energy market has changed dramatically, fuelled by technological change and fluctuations in commodity prices. This change is reflected in increased media attention as illustrated in Figure 2, which illustrates the variation in media attention to unconventional resources over the study period. The figure depicts the number of news articles published each year in the Wall street Journal that refer to unconventional resources. The graph suggests the possibility of changes in the impact of unconventional resources over time, and so we repeat the analysis using data drawn from four different subperiods.

The first sub-period is from 1989 to 1994 , which is reported in the fourth column of Table 8 . This is a period of relatively low oil and gas prices and limited interest in the market for unconventional resources. We argue that technological innovation was required to exploit these unconventional resources. More innovative technology was required to exploit these resources at this time, compared with that required to exploit conventional resources. Consistent with these observations, the coefficients estimated for the unconventional resource subsectors are generally negative, with the exception of the Coalbed methane and Heavy oil coefficients. ${ }^{15}$ It is important to note that the coefficients for shale gas/tight gas and shallow water are statistically significant at the $10 \%$ level. Thus, over this period on average,

\footnotetext{
${ }^{15}$ As an aside, we note that coalbed methane production increased substantially during this period and this may explain the positive though statistically insignificant coefficient for this dummy variable.
} 
acquisitions of these resources created less value for the acquirer compared with acquisition of conventional resources. We argue that the market valued these unconventional resource acquisitions less highly because of the greater level of technological complexity and uncertainty associated with them. This result is consistent with hypothesis $H I C$. The previous analysis focused on a simple comparison of the share market reaction to conventional and unconventional resource acquisition announcements in total over the full period of the study. The finer analysis, reported for the sub-periods, suggests the effect of technological innovation varies across the various classes of unconventional resource. Finally, the "other non-conventional" classification also has a negative and statistically significant coefficient for this period though it is not clear which of the elements that make up this class are driving this result.

In the following period, 1995 to 1999, oil prices were still low and the level of interest in unconventional resources was also still comparatively low (Figure 2). The coefficient for heavy oil is negative and significant only for this sub-period. It is argued that discovery and production of heavy oil is uneconomical when the price of crude oil is low (Ordonez 2007). Given the average oil price of less than \$20 during this period, the negative coefficient for acquisition of heavy oil is in line with Ordonez's finding. The remaining coefficients are generally statistically insignificant. Again, the "other non-conventional" classification is an exception though in this case it has a positive and statistically significant coefficient.

The third time period, 2000 to 2005, is a period when prices were rising and interest in exploiting unconventional resources was increasing. There is no significant difference in market reaction to acquisition of any of the sub-classifications of unconventional resources compared with the acquisition of conventional resources. The estimated coefficients are also generally positively signed. Finally, the fourth sub period, 2006 to 2011, was characterized 
by high and volatile prices and intense interest in exploitation of unconventional resources (See Figure 2). The only statistically significant coefficient (at the 10\% level) is that for the Deepwater resources. It is difficult to explain this result, particularly given the fallout from Deepwater Horizon explosion that occurred in 2010 (Sabet, Cam and Heaney, 2012). Separate analyses for the periods, 2000 to 2005 and 2006 to 2011 respectively, does not support hypothesis $H 1 C$.

The control variable coefficients reported in Table 8 are generally statistically insignificant though there are some exceptions; these concern the proxies for crude oil return volatility (Vol-Oil), firm size and growth. The significant coefficient of Vol-Oil suggests the share price reaction to acquisition announcements tends to be greater during periods of low crude oil price volatility when resource real option values would tend to be lower. Further, the unexpected share price reaction is greater for smaller firms, consistent with greater transparency associated with larger firms. Finally, the growth coefficients are negative and statistically insignificant for the full period though the sign and significance varies across the four sub-periods.

In summary, the share market reaction to resource acquisition announcements provides little evidence to support the existence of a broad technological innovation driven difference between conventional and unconventional resources. On analysis of unconventional resource sub-sectors, the differences that are observed relate to particular classifications early in the study period. In general, there is little consistency across classifications or sub-periods. Finally, the positive statistically significant constant term is consistent with earlier univariate tests supporting the argument that the announcement of the 
acquisition provides a costly signal of future positive NPV investment. These results are broadly in line with the univariate results reported before. ${ }^{16}$

\subsubsection{Divestitures}

Table 9 reports the results for the divestiture sample. Hypothesis $\mathrm{H} 2 \mathrm{C}$ predicts a positive coefficient for the unconventional resource sub sector dummy variables. Essentially, the announcement of divestiture of the more technologically complex unconventional resources is predicted to generate a more positive share market reaction than that expected on divestiture of conventional resources. The second column in Table 9 reports the coefficient on TECHDA, which estimates this difference for the whole sample period (1989-2011). This coefficient is positive and statistically significant at the $10 \%$ level of significance. While this supports hypothesis $H 2 C$, it is important to look more closely at the unconventional resource sub-sectors that might account for this result, as set out in the third column in Table 9. The shale gas/tight gas coefficient is the only statistically significant coefficient, with unconventional shale gas/tight gas divestitures increasing share value by $4.4 \%$ more than conventional shale gas divestitures consistent with hypothesis $H 2 C$.

We further explore the share market reaction to divestiture announcements using the sub-periods as defined in the previous acquisitions analysis (Table 8). There is evidence of a negative market reaction to divestiture of shale gas/tight gas sub sector relative to the divestiture of conventional resources from 1995-1999 though this reaction becomes positive and significant for the sub-periods 2000-2005 and 2006-2011. Thus, support for hypothesis $\mathrm{H} 2 \mathrm{C}$ is evident in the later part of the study period. A similar result is noted for liquefied natural gas with negative coefficient for the period 2000-2005 and positive coefficient in the

\footnotetext{
${ }^{16}$ This analysis was repeated using just the upstream resources. The results were little changed by restricting the sample in this way.
} 
following period, 2006 to 2011. The sign and statistical significance of the "other nonconventional" class varies over the sample period, similar to the results reported in Table 8 .

(Insert Table 9 about here)

Control variable coefficients are also reported for the divestiture analysis in Table 9. Natural gas (Vol-Gas) rather than crude oil (Vol-Oil) is the key volatility variable in this analysis. This suggests natural gas resources may be driving the divestitures in this study with considerable effect in the 2000 to 2005 sub-period though the coefficients are negative and statistically significant for the full period of the study similar to the crude oil volatility results reported in Table 8. Again, the unexpected share price reaction is greater for smaller firms though there are no statistically significant coefficients for the growth proxy. The ROA coefficient is negative and statistically significant for the sub period 1989 to 1994 , though this is not supported in the full period analysis.

In summary, the share market reaction to resource divestiture announcements provides some evidence to support the existence of a broad technology driven difference between conventional and unconventional resources. On analysis of unconventional resource sub-sectors, the results for liquefied natural gas and for shale gas/ tight gas provide some support for the hypothesized greater share price reaction to the announcement of divestiture of more technologically complex unconventional resources. Finally, the positive statistically significant constant terms provide some support for the argument that the announcement of the divestiture increases equity value as it predicts an increase in the volatility of returns to the resources remaining under the firm's control. These results are also broadly in line with 
the univariate results reported above though the identification of the importance of shale gas/tight gas is an important finding and this is further explored in the following subsection. ${ }^{17}$

\subsection{Shale gas investment}

Given the magnitude of the estimated coefficients in the analysis reported in Table 9 and the general importance of the shale gas/tight gas sector in the U.S. over the past ten years (Alonso and Mingo 2010; EIA 2011c; Medlock et al. 2011; Rogers 2011; Cahoy et al. 2012; Joskow 2013), we conduct further analysis of the shale gas transactions. The results in Table 8 suggest that acquisition of a shale gas resource generates a return that is not significantly different from that reported for conventional resources. Yet, Table 9 shows a significantly positive market response for divestiture of shale gas assets relative to conventional resources. We further explore this variation in Table 10, where it is found that, on average, acquisition of shale gas assets generates a 3-day CAR of $1.52 \%$ while the 3-day CAR reported for divestiture of shale gas assets is considerably larger $5.44 \%$. It should be noted that, while the return generated for the sellers of shale gas assets is more than three times the return generated for the acquirers of shale gas resources, the difference is not statistically significant for most event windows.

(Insert Table 10 about here)

\subsection{Portfolio analysis}

In their study, Hirshleifer et al. (2013) argue that investors do not fully impound news regarding technological innovation in the short term and there is evidence of mispricing between innovative efficiency and return. ${ }^{18}$ We examine this question further through analysis of long run and short run portfolio equity returns for firms that acquire oil and gas

\footnotetext{
${ }^{17}$ This analysis was repeated using just the upstream resources. The results were little changed by restricting the sample in this way.

${ }^{18}$ Hirshleifer et al. (2013) find that innovative efficiency, measured as patents and citations scaled by research and development expenditures, is a strong predictor of future returns.
} 
resources. We create three portfolios. The first is for firms that acquire conventional resources only (Conv) during the sample period. The second is for firms that acquired unconventional resources only (Unconv) and the third is for firms that acquired a combination of both conventional and unconventional resources (MIX). There are 1,282 acquisition announcements: 960 announcements belong to the MIX sample, 167 announcements belong to the conventional resources portfolio and 35 announcements belong to the unconventional resources portfolio. Table 11 reports the short-term and long-term returns for each of these portfolios. Buy and hold raw returns (Panel A) and buy and hold market adjusted returns (Panel B) are used to capture long-term returns to these investments. The long-term returns are measured over periods of 12, 24 and 36 months following the acquisition announcement date. ${ }^{19}$ The four-factor three-day average CAR (CAAR-FF) provides an estimate of the short-term return and these are reported in Panel B of Table 11.

\section{(Insert Table 11 about here)}

The raw returns reported in Panel A of Table 11 are positive and statistically significant for the three investment portfolios for 12, 24 and 36 month periods at the level of significance of $10 \%$ or better. There is also evidence that MIX portfolio returns are statistically significantly less than conventional portfolio returns for 12-month and 24-month return periods. Yet, there is no evidence of a statistically significant difference between conventional and unconventional resources long-term returns. These results do not support hypothesis $H 4$.

The raw returns results may just reflect compensation for risk and so we repeat the analysis using market-adjusted returns (Panel B of Table 11). The market adjusted MIX and conventional portfolio returns still exceed zero for the 12 month and 24 month portfolio

\footnotetext{
${ }^{19}$ The returns are raw returns and they are not scaled for each year.
} 
return periods (Panel B, Table 11) though there is no support for statistically significant longterm returns for the unconventional portfolio. Further, while the MIX 36-month market adjusted return is statistically significant this is not the case for either the conventional or unconventional 36-month market adjusted portfolio returns. Finally, there is no evidence to support existence of statistically significant differences in these long-term returns. Thus, there is no evidence to support hypothesis $H 4$.

In this study, we focused on the characteristics of the actual deal to see whether the deal is related to technological differences. The use of the content of the transaction in the capital acquisition announcement provides a more direct proxy than the patent data used in examining investor reaction to technological innovation related information by Hirshleifer et al. (2013). ${ }^{20}$ Contrary to the Hirshleifer et al. (2013), we find no significant difference in either short-term or long-term return to conventional relative to unconventional resources. Our findings tend to support an efficient market that fully impounds the information regarding technological innovation into stock prices on announcement day.

\section{Conclusion}

This study investigates the impact of the announcement of acquisition and divestiture of conventional and unconventional resources on the firm value. The development of technology has changed the shape of the oil and gas industry, and unconventional resources (shale gas, in particular) have had a profound impact on the nature of the oil and gas industry over the sample period. Using a sample of 1,282 acquisition and 1,503 divestiture announcements from 1989 to 2011, we find the market reacts positively to these announcements on average. Given the 3-day average CAR this reaction is statistically significant for conventional resource acquisitions and statistically insignificant for

\footnotetext{
${ }^{20}$ Hirshleifer et al. (2013) argue that investors showed inattention to innovative efficiency.
} 
unconventional resource acquisitions. Further, there is evidence of a positive wealth effect for matched conventional resource deals enjoyed by both the acquirer and seller. On average, the total wealth effect of acquisition and divestiture of conventional resources is $1.3 \%$. There is also evidence to suggest a greater return to smaller firms on average.

In addition, while market reaction to divestiture announcements of both conventional and unconventional resources is positive and significant, market reaction to divestiture of unconventional resources is significantly greater than market reaction to divestiture of conventional resources. We also run sub-period analyses for different subsectors of unconventional resources; evidence is found for sign variation in coefficients of the unconventional resource subsectors across the different sub-periods.

Finally, we create portfolios of oil and gas firms based on the nature of the acquisition i.e., conventional, unconventional and mixed. Analysis of long-term and short-term portfolio returns shows no significant difference in the return to investments in either conventional or unconventional resources. While this is inconsistent with the Hirshleifer et al. (2013) mispricing argument, it supports the alternate hypothesis that investors react to technology related and non-technology related acquisition announcements rapidly and in an unbiased manner, consistent with the efficient market hypothesis. 
Appendix A: Explanatory variable definitions.

\begin{tabular}{|c|c|}
\hline Code & Definition \\
\hline Vol-Oil & $\begin{array}{l}\text { Volatility of the last } 30 \text { futures price returns for the CME crude oil futures } \\
\text { contract (WTI) that ceases trading in the month prior to the month of the } \\
\text { announcement. All } 30 \text { daily returns are drawn from the one contract. }\end{array}$ \\
\hline Vol-Gas & $\begin{array}{l}\text { Volatility of the last } 30 \text { futures price returns for the CME natural gas futures } \\
\text { contract (Henry Hub) that ceases trading in the month prior to the month of } \\
\text { the announcement. All } 30 \text { daily returns are drawn from the one contract. }\end{array}$ \\
\hline Size & The natural log of total asset (Item AT) for the acquirer firm. \\
\hline $\begin{array}{l}\text { Growth } \\
\text { (Market to } \\
\text { book ratio } \\
(\mathrm{M} / \mathrm{B}))\end{array}$ & $\begin{array}{l}\text { The acquirer firm market value to book value (Item AT). Market value is } \\
\text { defined as total liability (Item LT) - Deferred taxes and investment tax credit } \\
\text { (Item TXDITC) +Preferred stock liquidation value (Item PSTKL) + market } \\
\text { value of equity (Items CSHO*PRCC_F) }\end{array}$ \\
\hline ROA & $\begin{array}{l}\text { The acquiring firm operating income before depreciation (Item OIBDP) } \\
\text { scaled by total assets (Item AT). }\end{array}$ \\
\hline Leverage & The acquirer firm total liability (Item LT) scaled by total asset (Item AT). \\
\hline Age & $\begin{array}{l}\text { This is the natural log of the number of years (AA) the firm has been listed } \\
\text { on the stock exchange. }\end{array}$ \\
\hline
\end{tabular}




\section{References}

Aharony, J., Swary, I., 1980. Quarterly dividend and earnings announcements and stockholders' returns: An empirical analysis. Journal of Finance 35, 1-12

Akhigbe, A., Martin, A.D., Whyte, A.M., 2007. Partial acquisitions, the acquisition probability hypothesis, and the abnormal returns to partial targets. Journal of Banking \& Finance 31, 3080-3101

Allen, P.R., Sirmans, C.F., 1987. An analysis of gains to acquiring firm's shareholders: The special case of REITs. Journal of Financial Economics 18, 175-184

Alonso, A., Mingo, M., 2010. The expansion of non conventional production of natural gas (tight gas, gas shale and coal bed methane). A silent revolution. In: Energy Market (EEM), 2010 7th International Conference on the European, pp. 1-8

Amihud, Y., Dodd, P., Weinstein, M., 1986. Conglomerate mergers, managerial motives and stockholder wealth. Journal of Banking \&amp; Finance 10, 401-410

Amihud, Y., Lev, B., 1981. Risk reduction as a managerial motive for conglomerate mergers. Bell Journal of Economics 12, 605-617

Asquith, P., Bruner, R.F., Mullins Jr, D.W., 1983. The gains to bidding firms from merger. Journal of Financial Economics 11, 121-139

Ball, R., Brown, P., 1968. An empirical evaluation of accounting income numbers. Journal of Accounting Research 6, 159-178

Barclay, M.J., Litzenberger, R.H., 1988. Announcement effects of new equity issues and the use of intraday price data. Journal of Financial Economics 21, 71-99

Bates, T.W., 2005. Asset sales, investment opportunities, and the use of proceeds. Journal of Finance 60, 105-135

Belenzon, S., 2012. Cumulative innovation and market value: Evidence from patent citations*. Economic Journal 122, 265-285

Boehmer, E., Masumeci, J., Poulsen, A.B., 1991. Event-study methodology under conditions of event-induced variance. Journal of Financial Economics 30, 253-272

Boone, J.P., 1998. Oil and gas reserve value disclosures and bid-ask spreads. Journal of Accounting and Public Policy 17, 55-84

Borna, J., Ryan, H.E., 2000. Capital expensiture announcements and anti-takeover barriers. Quarterly Review Of Economics And Finance 40, 205-228

Boyce, J.R., Nøstbakken, L., 2011. Exploration and development of U.S. oil and gas fields, 1955-2002. Journal of Economic Dynamics and Control 35, 891-908

Bradley, M., Desai, A., Kim, E.H., 1988. Synergistic gains from corporate acquisitions and their division between the stockholders of target and acquiring firms. Journal of Financial Economics 21, 3-40

Brailsford, Timothy J., Yeoh, D., 2004. Agency problems and capital expenditure announcements. Journal of Business 77, 223-256

Brigham, E.F., Tapley, T.C., 1985. Financial leverage and use of the net present value investment criterion: A reexamination. Financial Management 14, 48-52

Cahoy, D., Gehman, J., Lei, Z., 2012. Fracking patents: The emergence of patents as information containment Tools in Shale Drilling. Available at SSRN 2065032

Carhart, M.M., 1997. On persistence in mutual fund performance. Journal of Finance 52, 5782

Carlson, M., Khokher, Z., Titman, S., 2007. Equilibrium exhaustible resource price dynamics. Journal of Finance 62, 1663-1703 
Chan, S.H., Gau, G.W., Wang, K., 1995. Stock market reaction to capital investment decisions: Evidence from business relocations. Journal of Financial and Quantitative Analysis 30, 81-100

Chen, A.H., Merville, L.J., 1986. An analysis of divestiture effects resulting from deregulation. Journal of Finance 41, 997-1010

Chen, S.-S., Ho, K.W., 1997. Market response to product-strategy and capital-expenditure announcements in Singapore: Investment opportunities and free cash flow. Financial Management 26, 82-88

Chung, K.H., Wright, P., Charoenwong, C., 1998. Investment opportunities and market reaction to capital expenditure decisions. Journal of Banking \& Finance 22, 41-60

Click, R.W., Weiner, R.J., 2010. Resource nationalism meets the market: Political risk and the value of petroleum reserves. Journal of International Business Studies 41, 783-803

Coase, R.H., 1937. The nature of the firm. Economica 4, 386-405

Cochrane, J.H., 1991. Production-based asset pricing and the link between stock returns and economic fluctuations. Journal of Finance 46, 209-237

Cochrane, J.H., 1996. A Cross-sectional test of an investment-based asset pricing model. Journal of Political Economy 104, 572-621

Çolak, G., Whited, T.M., 2006. Spin-offs, divestitures, and conglomerate investment. Review of Financial Studies 20, 557-595

Cuddington, J.T., Moss, D.L., 2001. Technological change, depletion, and the U.S. petroleum industry. American Economic Review 91, 1135-1148

Da Silva Rosa, R., Nguyen, T., Walter, T., 2004, Market returns to acquirers of substantial assets, Australian Journal of Management, 29, 111-133

Datta, S., E. Iskandar-Datta, M., 1995. Corporate partial acquisitions, total firm valuation and the effect of financing method. Journal of Banking \& Finance 19, 97-115

EIA, 2011. World Shale Gas Resources: An Initial Assessment of 14 Regions Outside the United States, US Department of Energy, Washington, DC

EIA, 2015, Quadrennial Technology Review: An Assessment of Energy Technologies and Research Opportunities, US Department of Energy, Washington, DC

Faccio, M., Masulis, R.W., 2005. The choice of payment method in European mergers and acquisitions. Journal of Finance 60, 1345-1388

Fagan, M.N., 1997. Resource depletion and technical change: Effects on U.S. crude oil finding costs from 1977 to 1994. The Energy Journal 18, 91-105

Fama, E.F., Fisher, L., Jensen, M.C., Roll, R.W., 1969. The adjustment of stock prices to new information. International Economic Review, Vol. 10, February 1969

Fama, E.F., French, K.R., 1992. The cross-section of expected stock returns. Journal of Finance 47, 427-465

Fluck, Z., Lynch, Anthony W., 1999. Why do firms merge and then divest? A theory of financial synergy. Journal of Business 72, 319-346

Forbes, K.F., Zampelli, E.M., 2000. Technology and the exploratory success rate in the u.s. offshore. Energy Journal 21, 109-120

Forbes, K.F., Zampelli, E.M., 2002. Technology and the exploratory success rate in the US onshore. Quarterly Review of Economics and Finance 42, 319-334

Fu, F., Lin, L., Officer, M.S., 2013. Acquisitions driven by stock overvaluation: Are they good deals? Journal of Financial Economics 109, 24-39

Fuller, K., Netter, J., Stegemoller, M., 2002. What do returns to acquiring firms tell us? Evidence from firms that make many acquisitions. Journal of Finance 57, 1763-1793

Galai, D., Masulis, R.W., 1976. The option pricing model and the risk factor of stock. Journal of Financial Economics 3, 53-81 
Ghicas, D., Pastena, V., 1989. The acquisition value of oil and gas firms: The role of historical costs, reserve recognition accounting, and analysts' appraisals. Contemporary Accounting Research 6, 125-142

Greenwood, J., Jovanovic, B., 1999. The information-technology revolution and the stock market. American Economic Review 89, 116-122

Grullon, G., Lyandres, E., Zhdanov, A., 2012. Real options, volatility, and stock returns. Journal of Finance 67, 1499-1537

Halpern, P., 1983. Corporate acquisitions: A theory of special cases? A review of event studies applied to acquisitions. Journal of Finance 38, 297-317

Harford, J., Humphery-Jenner, M., Powell, R., 2012. The sources of value destruction in acquisitions by entrenched managers. Journal of Financial Economics

Harris, T.S., Ohlson, J.A., 1987. Accounting disclosures and the market's valuation of oil and gas properties. Accounting Review 62, 651-670

Haushalter, G.D., Heron, R.A., Lie, E., 2002. Price uncertainty and corporate value. Journal of Corporate Finance 8, 271-286

Healy, P.M., Palepu, K.G., Ruback, R.S., 1992. Does corporate performance improve after mergers? Journal of Financial Economics 31, 135-175

Higgins, M.J., Rodriguez, D., 2006. The outsourcing of R\&D through acquisitions in the pharmaceutical industry. Journal of Financial Economics 80, 351-383

Hirshleifer, D., Hsu, P.-H., Li, D., 2013. Innovative efficiency and stock returns. Journal of Financial Economics 107, 632-654

Hirshleifer, D., Lim, S.S., Teoh, S.H., 2009. Driven to distraction: extraneous events and underreaction to earnings news. Journal of Finance 64, 2289-2325

Hite, G.L., Owers, J.E., Rogers, R.C., 1987. The market for interfirm asset sales: Partial selloffs and total liquidations. Journal of Financial Economics 18, 229-252

Hobijn, B., Jovanovic, B., 2001. The information-technology revolution and the stock market: evidence. American Economic Review 91, 1203-1220

Hsu, K.-C., Wright, M., Zhu, Z., 2017, What motivates merger and acquisition activities in the upstream oil and gas sectors in the U.S.? Energy Economics, 65, 240-250

Huberman, G., Regev, T., 2001. Contagious speculation and a cure for cancer: a nonevent that made stock prices soar. Journal of Finance 56, 387-396

Jain, B.A., Kini, O., Shenoy, J., 2011. Vertical divestitures through equity carve-outs and spin-offs: A product markets perspective. Journal of Financial Economics 100, 594615

Jain, P.C., 1985. The effect of voluntary sell-off announcements on shareholder wealth. Journal of Finance 40, 209-224

Jensen, M.C., 1986. Agency costs of free cash flow, corporate finance, and takeovers. American Economic Review 76, 323-329

John, K., Ofek, E., 1995. Asset sales and increase in focus. Journal of Financial Economics $37,105-126$

Jones , E., Danbolt, J., Hirst, I., 2004. Company investment announcements and the market value of the firm. European Journal of Finance 10, 437-452

Joskow, P.L., 2013. Natural Gas: From Shortages to Abundance in the United States. American Economic Review 103, 338-43

Kaplan, S.N., Weisbach, M.S., 1992. The success of acquisitions: evidence from divestitures. Journal of Finance 47, 107-138

Kerstein, J., Kim, S., 1995. The incremental information content of capital expenditures. Accounting Review 70, 513-526

Kim, C.E., 1998. The effects of asset liquidity: Evidence from the contract drilling industry. Journal of Financial Intermediation 7, 151-176 
Klibanoff, P., Lamont, O., Wizman, T.A., 1998. Investor reaction to salient news in closedend country funds. Journal of Finance 53, 673-699

Kolari, J.W., Pynnönen, S., 2010. Event study testing with cross-sectional correlation of abnormal returns. Review of Financial Studies 23, 3996-4025

Laitner, J., Stolyarov, D., 2003. Technological change and the stock market. American Economic Review 93, 1240-1267

Lang, L.H.P., Stulz, R., Walkling, R.A., 1989. Managerial performance, Tobin's Q, and the gains from successful tender offers. Journal of Financial Economics 24, 137-154

Levy, H., Sarnat, M., 1970. Diversification, portfolio analysis and the uneasy case for conglomerate mergers. Journal of Finance 25, 795-802

Lind, B., Plott, C.R., 1991. The winner's curse: experiments with buyers and with sellers. American Economic Review 81, 335-346

Loughran, T., Ritter, J.R., 2003. Why has IPO underpricing changed over time? AFA Washington, DC Meetings. Available at SSRN: https://ssrn.com/abstract=331780

Magliolo, J., 1986. Capital market analysis of reserve recognition accounting. Journal of Accounting Research 24, 69-108

Managi, S., Opaluch, J.J., Jin, D., Grigalunas, T.A., 2005. Technological change and petroleum exploration in the Gulf of Mexico. Energy Policy 33, 619-632

Maquieira, C.P., Megginson, W.L., Nail, L., 1998. Wealth creation versus wealth redistributions in pure stock-for-stock mergers. Journal of Financial Economics 48, 333

Masulis, R.W., Wang, C., Xie, F.E.I., 2007. Corporate governance and acquirer returns. Journal of Finance 62, 1851-1889

Matolcsy, Z.P., Wyatt, A., 2008. The association between technological conditions and the market value of equity. Accounting Review 83, 479-518

McConnell, J.J., Muscarella, C.J., 1985. Corporate capital expenditure decisions and the market value of the firm. Journal of Financial Economics 14, 399-422

Melicher, R.W., Rush, D.F., 1973. The performance of conglomerate firms: recent risk and return experience. Journal of Finance 28, 381-388

Melicher, R.W., Rush, D.F., 1974. Evidence on the acquisition-related performance of conglomerate firms. Journal of Finance 29, 141-149

Merton, H.M., Upton, C.W., 1985. A test of the hotelling valuation principle. Journal of Political Economy 93, 1-25

Mitchell, M.L., Mulherin, J.H., 1994. The impact of public information on the stock market. Journal of Finance 49, 923-950

Moeller, S.B., Schlingemann, F.P., Stulz, R.M., 2004. Firm size and the gains from acquisitions. Journal of Financial Economics 73, 201-228

Moeller, S.B., Schlingemann, F.P., Stulz, R.M., 2005. Wealth destruction on a massive scale? A study of acquiring-firm returns in the recent merger wave. Journal of Finance 60, 757-782

Mohn, K., Misund, B., 2009. Investment and uncertainty in the international oil and gas industry. Energy Economics 31, 240-248

Mohn, K., Misund, B., 2011. Shifting sentiments in firm investment: an application to the oil industry. Applied Financial Economics 21, 469-479

Montgomery, C.A., Singh, H., 1984. Diversification strategy and systematic risk. Strategic Management Journal 5, 181-191

Mulherin, J.H., Boone, A.L., 2000. Comparing acquisitions and divestitures. Journal of Corporate Finance 6, 117-139 
Myers, S.C., Majluf, N.S., 1984, Corporate financing and investment decisions when firms have information that investors do not have, Journal of Financial Economics, 13, 187 221

Ng, A, Donker, H., 2013, Purchasing reserves and commodity market timing as takeover motives in the oil and gas industry, Energy Economics, 37, 167-181

Ordonez, I., 2007. Energy: Oil giants leave more than oil behind in Venezuela --- firms' technology, Expertise May Fall

Into Hands of Rivals. In: The Wall Street Journal. Dow Jones \& Company

Pástor, L., Veronesi, P., 2009. Technological revolutions and stock prices. American Economic Review 99, 1451-1483

Raghavendra Rau, P., Vermaelen, T., 1998. Glamour, value and the post-acquisition performance of acquiring firms. Journal of Financial Economics 49, 223-253

Rogers, H., 2011. Shale gas - the unfolding story. Oxford Review of Economic Policy 27, 117-143

Roll, R., 1986. The hubris hypothesis of corporate takeovers. Journal of Business 59, 197-216

Rosenfeld, J.D., 1984. Additional evidence on the relation between divestiture announcements and shareholder wealth. Journal of Finance 39, 1437-1448

Rossi, S., Volpin, P.F., 2004. Cross-country determinants of mergers and acquisitions. Journal of Financial Economics 74, 277-304

Sabet, A. H., Cam, M.-A., Heaney, R., 2012, Share market reaction to the BP oil spill and the US Government moratorium on exploration, Australian Journal of Management, 37, 61-76.

Sabet, A. H., Heaney, R., 2016, An event study analysis of oil and gas firm acreage and reserve acquisitions, Energy Economics, 57, 215-227

Schlingemann, F.P., Stulz, R.M., Walkling, R.A., 2002. Divestitures and the liquidity of the market for corporate assets. Journal of Financial Economics 64, 117-144

Servaes, H., 1991. Tobin's Q and the gains from takeovers. Journal of Finance 46, 409-419

Shleifer, A., Vishny, R.W., 1989. Management entrenchment: The case of manager-specific investments. Journal of Financial Economics 25, 123-139

Sicherman, N.W., Pettway, R.H., 1987. Acquisition of divested assets and shareholders' wealth. Journal of Finance 42, 1261-1273

Sicherman, N.W., Pettway, R.H., 1992. Wealth effects for buyers and sellers of the same divested assets. Financial Management 21, 119-128

Tetlock, P.C., 2007. Giving content to investor sentiment: The role of media in the stock market. Journal of Finance 62, 1139-1168

Tobin, J., Brainard, W., C., 1976. Asset Markets and the Cost of Capital. Cowles Foundation for Research in Economics, Yale University

Trautwein, F., 1990. Merger motives and merger prescriptions. Strategic Management Journal 11, 283-295

Uysal, V.B., 2011. Deviation from the target capital structure and acquisition choices. Journal of Financial Economics 102, 602-620

Vogt, S.C., 1997. Cash flow and capital spending: Evidence from capital expenditure announcements. Financial Management 26, 44-57

Warusawitharana, M., 2008. Corporate asset purchases and sales: Theory and evidence. Journal of Financial Economics 87, 471-497

Weston, J.F., Mansinghka, S.K., 1971. Tests of the efficiency performance of conglomerate firms. Journal of Finance 26, 919-936

Weston, J.F., SIU, J.A., Johnson, B.A., 2001. Takeover, Restructuring and Corporate Governance. Upper Saddle. 
Woods, J.C., Randall, M.R., 1989. The net present value of future investment opportunities: Its Impact on Shareholder Wealth and Implications for Capital Budgeting Theory. Financial Management 18, 85-92

Woolridge, J.R., 1988. Competitive decline and corporate restructuring: Is a myopic stock market to blame? Journal of Applied Corporate Finance 1, 26-36

Woolridge, J.R., Snow, C.C., 1990. Stock market reaction to strategic investment decisions. Strategic Management Journal 11, 353-363

Zaima, J.K., Hearth, D., 1985. The wealth effects of voluntary selloffs: Implications for divesting and acquiring firms. Journal of Financial Research 8, 227-236 
Table 1: Description of the sample

\begin{tabular}{|c|c|c|}
\hline Filtering Criteria & $\begin{array}{l}\text { Number of } \\
\text { acquisition } \\
\text { deals }\end{array}$ & $\begin{array}{c}\text { Number of } \\
\text { divestiture } \\
\text { deals }\end{array}$ \\
\hline Herold mergers and acquisitions available for analysis & 33,542 & 33,542 \\
\hline Exclude deals involving firms not in the CRSP and Compustat database & $-25,306$ & $-27,237$ \\
\hline Subtotal & 8,236 & 6,305 \\
\hline $\begin{array}{l}\text { Constrain deals to acquisition of acreage \& reserves (upstream), oil field } \\
\text { services, downstream and midstream-only assets. }\end{array}$ & $-4,007$ & $-2,190$ \\
\hline Subtotal & 4,229 & 4,115 \\
\hline $\begin{array}{l}\text { Restrict deals to meet the following criteria: } 1 \text {. Deal type is } \\
\text { acquisition, farm in or joint venture. } 2 \text {. Deal status is equal to complet }\end{array}$ & $-1,974$ & $-1,204$ \\
\hline Subtotal & 2,255 & 2,911 \\
\hline $\begin{array}{l}\text { Exclude deals not available in SDC platinum and Factiva database, firms with } \\
\text { insufficient share returns during estimation and event period and deals with } \\
\text { certain announcements during event period (See Section } 3 \text { ). }\end{array}$ & -973 & $-1,401$ \\
\hline Final Sample for Analysis & 1,282 & 1,510 \\
\hline
\end{tabular}




\section{Table 2: Descriptive statistics}

This table reports descriptive statistics for the explanatory variables used in regression analysis reported in Tables 8 and 9. Vol-Oil and Vol-Gas refer to volatility estimates calculated for the CME Group crude oil (WTI) and natural gas (Henry Hub) futures contracts respectively. These volatility estimates are calculated using the last 30 daily futures returns for the contract that ceases trading in the month immediately preceding the announcement month. The natural log of total assets (item AT) is used as a proxy for the size of the firm (Size). The proxy for the firm's growth options (Growth) is the ratio of market value to book value of assets, where the book value is equal to the firm's total assets (Item AT) and market value of the firm is calculated as market value of the equity (Item CSHO*Item PTCC_F) plus preferred stock (Item PSTKL) plus liabilities (Item LT) minus balance sheet deferred taxes and investment tax credit (Item TXDITC). ROA is the firm earnings before interest and taxes (EBIT) divided by total asset (Item AT). Leverage is calculated as total liabilities to total assets. Firm age (Age) is the natural log of the number of years the firm has been listed on the stock exchange (AA). All of the variables are selected from the reporting period preceding the announcement date.

Panel A: Acquisition of resource $(\mathrm{N}=1,282)$

\begin{tabular}{lccccccc}
\hline Variable & Mean & Sd & Min & P5 & P50 & P95 & Max \\
\hline Vol-oil & 0.175 & 0.121 & 0.013 & 0.033 & 0.135 & 0.405 & 0.555 \\
Vol-gas & 0.171 & 0.125 & 0.007 & 0.037 & 0.146 & 0.394 & 0.920 \\
AT & 28,789 & 61,010 & 4 & 46 & 2,829 & 183,096 & 322,560 \\
Size & 7.957 & 2.503 & 1.344 & 3.826 & 7.948 & 12.118 & 12.684 \\
Growth & 1.533 & 0.840 & 0.454 & 0.918 & 1.363 & 2.616 & 18.898 \\
ROA & 0.153 & 0.132 & -1.102 & -0.065 & 0.168 & 0.298 & 0.702 \\
Leverage & 0.542 & 0.175 & 0.023 & 0.234 & 0.550 & 0.786 & 1.499 \\
AA & 25.433 & 14.119 & 4.000 & 7.000 & 22.000 & 51.000 & 51.000 \\
Age & 3.065 & 0.613 & 1.386 & 1.946 & 3.091 & 3.932 & 3.932 \\
\hline Panel B: Divestiture of resource $(\mathrm{N}=1,503)$ & & & & \\
\hline Vol-oil & 0.163 & 0.119 & 0.013 & 0.032 & 0.120 & 0.392 & 0.555 \\
Vol-gas & 0.162 & 0.120 & 0.007 & 0.022 & 0.126 & 0.394 & 0.895 \\
AT & 46,534 & 72,982 & 5 & 110 & 11,613 & 219,015 & 322,560 \\
Size & 9.036 & 2.344 & 1.528 & 4.696 & 9.350 & 12.297 & 12.684 \\
Growth & 1.408 & 0.584 & 0.368 & 0.849 & 1.288 & 2.312 & 8.567 \\
ROA & 0.147 & 0.130 & -0.796 & -0.044 & 0.153 & 0.287 & 2.000 \\
Leverage & 0.581 & 0.163 & 0.001 & 0.362 & 0.574 & 0.802 & 2.000 \\
AA & 30.995 & 15.650 & 4.000 & 8.000 & 27.000 & 51.000 & 51.000 \\
Age & 3.274 & 0.608 & 1.386 & 2.079 & 3.296 & 3.932 & 3.932 \\
\hline
\end{tabular}




\section{Table 3: Spearman rank correlation coefficients}

This table provides a matrix of Spearman rank correlation coefficients for the explanatory variables. ***,** and * refer to $1 \%, 5 \%$ and $10 \%$ level of significance respectively. Variables are defined in Table 2.

Panel A: Acquisition of Assets

\begin{tabular}{|c|c|c|c|c|c|c|}
\hline & Vol-Oil & Vol-Gas & Size & Growth & ROA & Leverage \\
\hline Vol-Gas & $0.69^{* * *}$ & & & & & \\
\hline Size & $0.16^{* * *}$ & $0.05^{*}$ & & & & \\
\hline Growth & $0.14^{* * *}$ & $0.22 * * *$ & $-0.15 * * *$ & & & \\
\hline ROA & $0.26^{* * *}$ & $0.24 * * *$ & $0.32^{* * *}$ & 0.22 & & \\
\hline Leverage & -0.02 & -0.04 & $0.22^{* * *}$ & $-0.11 * * * *$ & $-0.08 * * *$ & \\
\hline Age & $-0.11^{* *}$ & $-0.06 * *$ & $0.23^{* * *}$ & $-0.07^{* *}$ & $0.14 * * *$ & $0.06^{* *}$ \\
\hline \multicolumn{7}{|c|}{ Panel B: Divestiture of assets } \\
\hline & Vol-Oil & Vol-Gas & Size & Growth & ROA & Leverage \\
\hline Vol-Gas & $0.69 * * *$ & & & & & \\
\hline Size & $0.18 * * *$ & $0.15 * * *$ & & & & \\
\hline Growth & $0.18^{* * *}$ & & $0.09 * * *$ & & & \\
\hline ROA & $0.33^{* * *}$ & & $0.35^{* * *}$ & $0.34 * * *$ & & \\
\hline Leverage & $-0.14 * * *$ & $0.10 * * *$ & $-0.11 * * *$ & $-0.24 * * *$ & $-0.24 * * *$ & \\
\hline Age & $-0.12 * * *$ & $-0.08 * * *$ & $0.31^{* * *}$ & $0.08 * * *$ & $0.07 * * *$ & 0.02 \\
\hline
\end{tabular}


Table 4: Classification of oil and gas firms by broad segments

Panel A: Broad Segment Summaries

\begin{tabular}{|c|c|c|c|c|}
\hline \multirow[t]{2}{*}{ Key Characteristic } & \multicolumn{2}{|c|}{ Acquisition } & \multicolumn{2}{|c|}{ Divestiture } \\
\hline & Frequency & Percent & Frequency & Percent \\
\hline \multicolumn{5}{|l|}{ Conventional } \\
\hline Conventional & 737 & 57.49 & 918 & 61.08 \\
\hline \multicolumn{5}{|l|}{ Unconventional } \\
\hline Coalbed Methane & 35 & 2.73 & 35 & 2.33 \\
\hline Deepwater & 125 & 9.75 & 148 & 9.85 \\
\hline Heavy Oil & 27 & 2.11 & 34 & 2.26 \\
\hline Liquefied Natural Gas & 24 & 1.87 & 20 & 1.33 \\
\hline Other non-conventional & 66 & 5.15 & 28 & 1.86 \\
\hline Shallow Water & 121 & 9.44 & 247 & 16.43 \\
\hline Tight Gas/Shale Gas & 147 & 11.47 & 73 & 4.86 \\
\hline Total & 1,282 & 100.00 & 1,503 & 100.00 \\
\hline
\end{tabular}

Panel B: Broad Segment by Sector

\begin{tabular}{|c|c|c|c|c|c|c|c|c|c|c|}
\hline \multirow[t]{2}{*}{ Key Characteristic } & \multicolumn{5}{|c|}{ Acquisition } & \multicolumn{5}{|c|}{ Divestiture } \\
\hline & Down & Mids & & Upst & Total & Down & Mids & Oilf & Upst & Total \\
\hline \multicolumn{11}{|l|}{ Conventional } \\
\hline Conventional & 29 & & & 678 & 737 & 40 & 20 & & 858 & 918 \\
\hline \multicolumn{11}{|l|}{ Unconventional } \\
\hline Coalbed Methane & & 3 & & 32 & 35 & & 1 & & 34 & 35 \\
\hline Deepwater & & & 4 & 121 & 125 & & 3 & 10 & 135 & 148 \\
\hline Heavy Oil & 1 & 1 & & 25 & 27 & & 3 & 10 & 135 & 148 \\
\hline Liquefied Natural Gas & 11 & 5 & & 8 & 24 & & 1 & & 33 & 34 \\
\hline Other non- & 2 & 1 & 3 & 60 & 66 & 10 & 3 & & 7 & 20 \\
\hline Shallow Water & & & & 121 & 121 & 1 & 2 & 1 & 24 & 28 \\
\hline Tight Gas/Shale Gas & & 23 & 2 & 122 & 147 & & & 3 & 244 & 247 \\
\hline Total & 43 & 63 & 9 & 1,167 & 1,282 & 51 & 50 & 15 & 1,387 & 1,503 \\
\hline
\end{tabular}

"Down" refers to downstream, "Mids" refers to midstream, "Oilf" refers to oilfield and "Upst" refers to upstream. 
Table 5: Announcement frequency by year

\begin{tabular}{|c|c|c|c|c|c|c|}
\hline \multirow{2}{*}{ YEAR } & \multicolumn{3}{|c|}{ Acquisition } & \multicolumn{3}{|c|}{ Divestiture } \\
\hline & Conventional & Unconventional & Total & Conventional & Unconventional & Total \\
\hline \multirow[t]{2}{*}{1989} & & 1 & 13 & & & 23 \\
\hline & 12 & & & 23 & 0 & \\
\hline \multirow[t]{2}{*}{1990} & & 1 & 6 & & & 30 \\
\hline & 5 & & & 26 & 4 & \\
\hline \multirow[t]{2}{*}{1991} & & 1 & 22 & & & 47 \\
\hline & 21 & & & 46 & 1 & \\
\hline \multirow[t]{2}{*}{1992} & & 2 & 16 & & & 26 \\
\hline & 14 & & & & 1 & \\
\hline \multirow[t]{2}{*}{1993} & & 4 & 29 & & & 28 \\
\hline & 25 & & & & 3 & \\
\hline \multirow[t]{2}{*}{1994} & & 3 & 32 & & & 21 \\
\hline & 29 & & & 18 & 3 & \\
\hline \multirow[t]{2}{*}{1995} & & 3 & 27 & & & 40 \\
\hline & 24 & & & 37 & 3 & \\
\hline \multirow[t]{2}{*}{1996} & & 2 & 46 & & & 57 \\
\hline & 44 & & & 52 & 5 & \\
\hline \multirow[t]{2}{*}{1997} & & 5 & 49 & & & 64 \\
\hline & 44 & & & 51 & 13 & \\
\hline \multirow{2}{*}{1998} & & 6 & 45 & & & 67 \\
\hline & 39 & & & 60 & 7 & \\
\hline \multirow[t]{2}{*}{1999} & & 15 & 45 & & & 68 \\
\hline & 30 & & & 52 & 16 & \\
\hline \multirow[t]{2}{*}{2000} & & 12 & 41 & & & 37 \\
\hline & 29 & & & 25 & 12 & \\
\hline \multirow[t]{2}{*}{2001} & & 23 & 47 & & & 38 \\
\hline & . & & & 20 & 18 & \\
\hline \multirow[t]{2}{*}{2002} & & 14 & 42 & & & 57 \\
\hline & 28 & & & 37 & 20 & \\
\hline \multirow[t]{2}{*}{2003} & & 20 & 48 & & & 63 \\
\hline & 28 & & & 40 & 23 & \\
\hline \multirow[t]{2}{*}{2004} & & 26 & 70 & & & 82 \\
\hline & 44 & & & 45 & 37 & \\
\hline \multirow[t]{2}{*}{2005} & & 48 & 102 & & & 90 \\
\hline & 54 & & & 32 & 58 & \\
\hline \multirow[t]{2}{*}{2006} & & 49 & 86 & & & 114 \\
\hline & 37 & & & 47 & 67 & \\
\hline
\end{tabular}


2007

44

2008

33

2009

38

2010

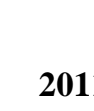

2011

737

39

Total
57

69

39

74

71
101

61

102

77

110

26

48

61

61

66

47
109

95

127

87 
Table 6: Event study, conventional and unconventional assets

This table provides an overview of the market response to acquisition and divestiture announcements. Panel A reports the market reaction to announcements of acquisitions of conventional and unconventional resources and Panel B reports the market reaction to announcements of divestiture of conventional and unconventional resources. The parameters for expected return in Panel A and B are calculated over days -269 to -11, where day 0 is the announcement date. The parameters of expected return are calculated using the Carhart (1990) four factor model. For average CARs, t-statistics are calculated using the standardized cross-sectional method of Boehmer et al. (1991). The ***, ** and * refer to significance at the $1 \%, 5 \%$ and $10 \%$ levels, respectively.

Conventional

$(\mathrm{N}=737)$

(1)

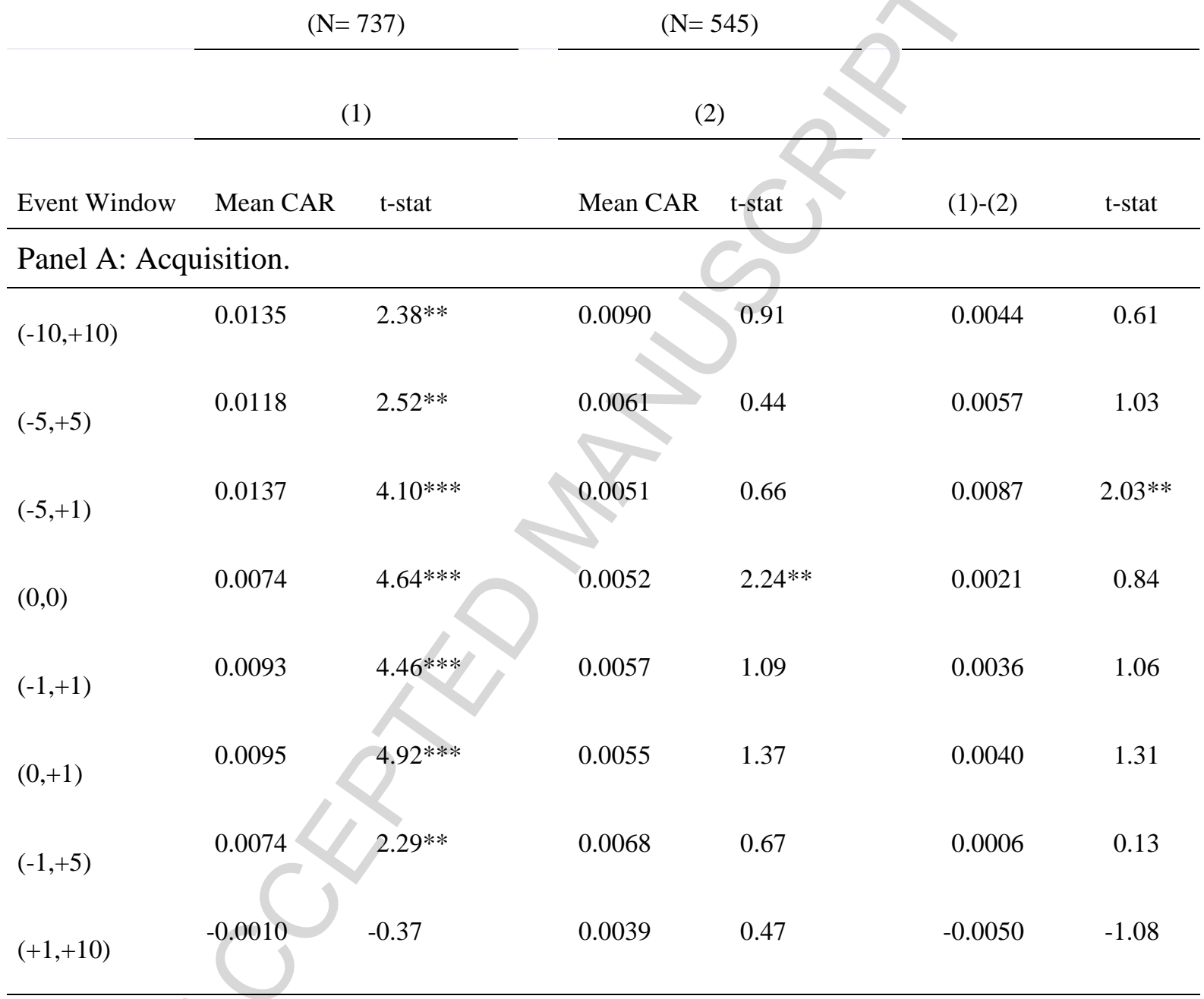

Panel B: Divestiture.
Unconventional

Difference

rarar

\begin{tabular}{|c|c|c|c|c|c|c|}
\hline & & 17) & & & & \\
\hline & & & & & $(1)-(2)$ & t-stat \\
\hline$(-10,+10)$ & 0.0071 & $2.23 * *$ & 0.0184 & $2.88^{* * *}$ & -0.0113 & -1.26 \\
\hline$(-5,+5)$ & 0.0071 & $2.32 * *$ & 0.0152 & $3.04 * * *$ & -0.0082 & -1.37 \\
\hline
\end{tabular}




\begin{tabular}{|c|c|c|c|c|c|c|}
\hline$(-5,+1)$ & 0.0089 & $2.91 * * *$ & 0.0165 & $4.96 * * *$ & -0.0076 & -1.46 \\
\hline$(0,0)$ & 0.0066 & $3.55 * * *$ & 0.0064 & $2.25 * *$ & 0.0003 & 0.09 \\
\hline$(-1,+1)$ & 0.0079 & $3.72 * * *$ & 0.0116 & $3.17 * * *$ & -0.0036 & -0.82 \\
\hline$(0,+1)$ & 0.0064 & $3.37 * * *$ & 0.0096 & $2.79 * * *$ & -0.0032 & -0.80 \\
\hline$(-1,+5)$ & 0.0061 & $2.68 * * *$ & 0.0121 & $2.35 * *$ & -0.0060 & -1.16 \\
\hline$(+1,+10)$ & -0.0012 & 1.01 & 0.0028 & 0.68 & -0.0040 & -0.70 \\
\hline
\end{tabular}


Table 7: Combined effect of acquisition and divestiture.

EWCAR and VWCAR refer to the equally weighted and value weighted 3-day CARs to the matched acquisition and divestiture pairs. The parameters for expected return are calculated over days -269 to - 11 , where day 0 is the announcement date. The parameters for expected return are calculated using the Carhart (1997) four-factor model. $* * *, * *$ and $*$ refer to the $1 \%, 5 \%$ and $10 \%$ level of significance respectively.

\begin{tabular}{l|cccc}
\hline \multirow{2}{*}{ Mean } & \multicolumn{2}{|c}{ Conventional } & \multicolumn{2}{c}{ Unconventional } \\
\hline Std Dev & EWCAR & VWCAR & EWCAR & VWCAR \\
Min & 0.0133 & 0.0056 & 0.0162 & 0.0061 \\
Max & 0.051 & 0.0412 & 0.0947 & 0.0571 \\
$\mathrm{~N}$ & -0.158 & -0.109 & -0.131 & -0.099 \\
Median & 0.310 & 0.247 & 0.913 & 0.396 \\
$\mathrm{t}-\mathrm{value}$ & 172 & 172 & 141 & 141 \\
Pr $>|\mathrm{t}|$ & 0.0082 & 0.0072 & 0.0024 & -0.0003 \\
\hline
\end{tabular}


Table 8: Regression analysis: Acquisitions

The dependent variable is the cumulative abnormal return estimated using the Carhart (1997) four factor model three days around the announcement date. TECHDA is an indicator variable equals to one if the transaction is related to unconventional resources, and zero otherwise. Coalbed Methane, Deepwater, Heavy oil, Liquified Natural gas, other non-conventional, shallow water and shale gas are indicator variables for each of the unconventional segments. Control variables are defined in Appendix A. Robust standard errors clustered by firm are reported in parenthesis below the estimated coefficient. The ***,** and * refer to $1 \%, 5 \%$ and $10 \%$ level of significance respectively.

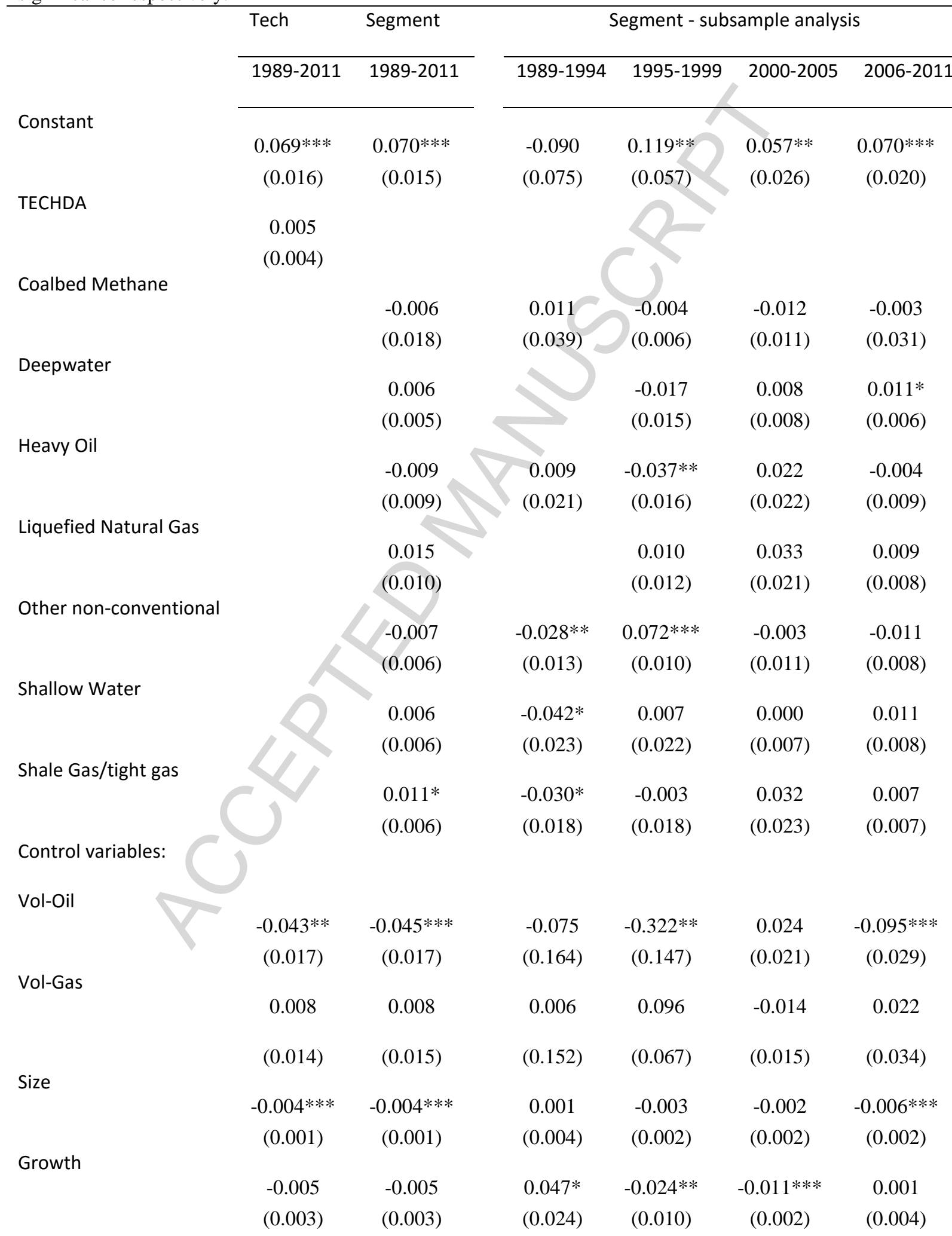




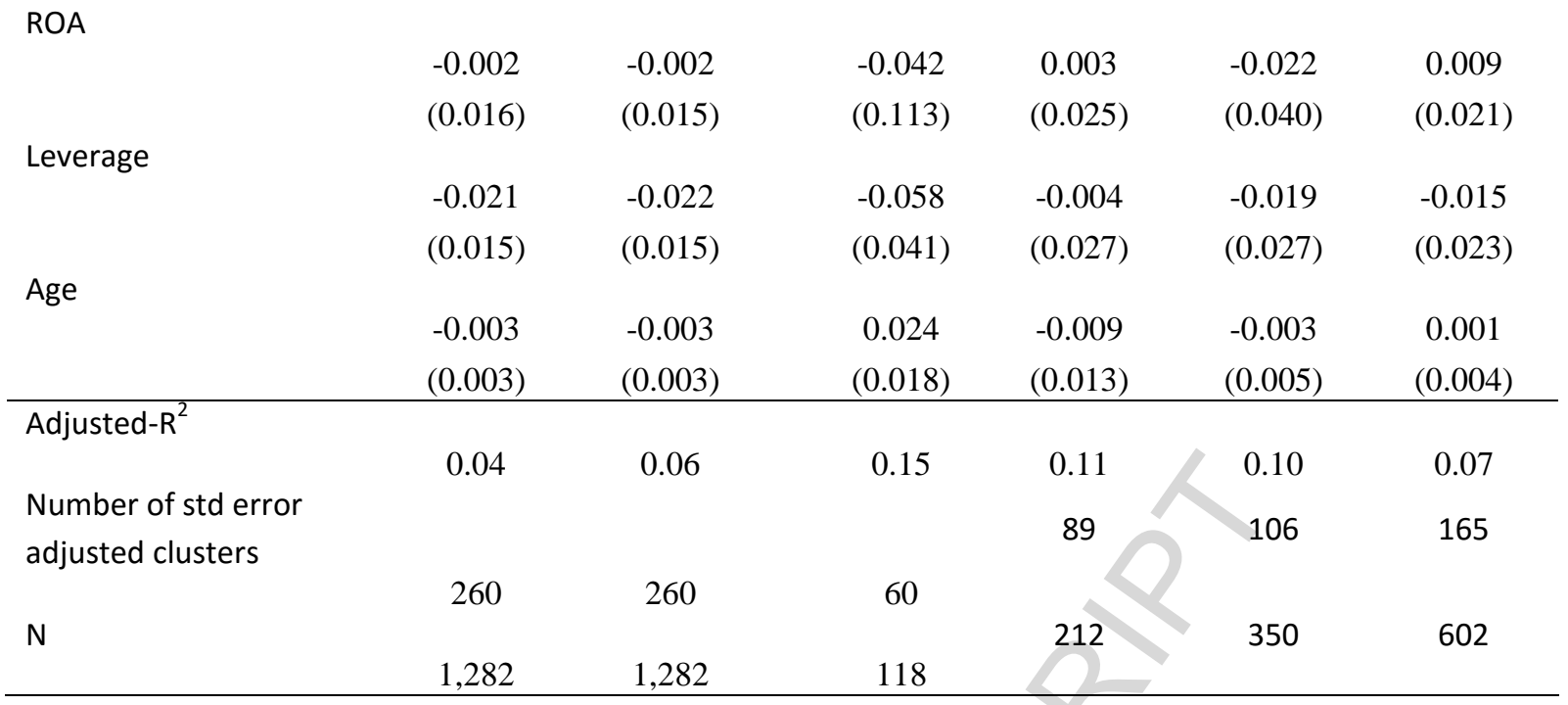


Table 9: Regression analysis: Divestitures

The dependent variable is the cumulative abnormal return estimated using the Fama French Carhart four factor model three days around the announcement date. TECHDA is an indicator variable equals to one if the transaction is related to unconventional resources, and zero otherwise. Coalbed Methane, Deepwater, Heavy oil, Liquified Natural gas, other non-conventional, shallow water and shale gas are indicator variables for each of the unconventional resources segments. Control variables are defined in Appendix A. Robust standard errors clustered by firm are reported in parenthesis below the estimated coefficient The ***, ** and $*$ refer to $1 \%, 5 \%$ and $10 \%$ level of significance respectively.

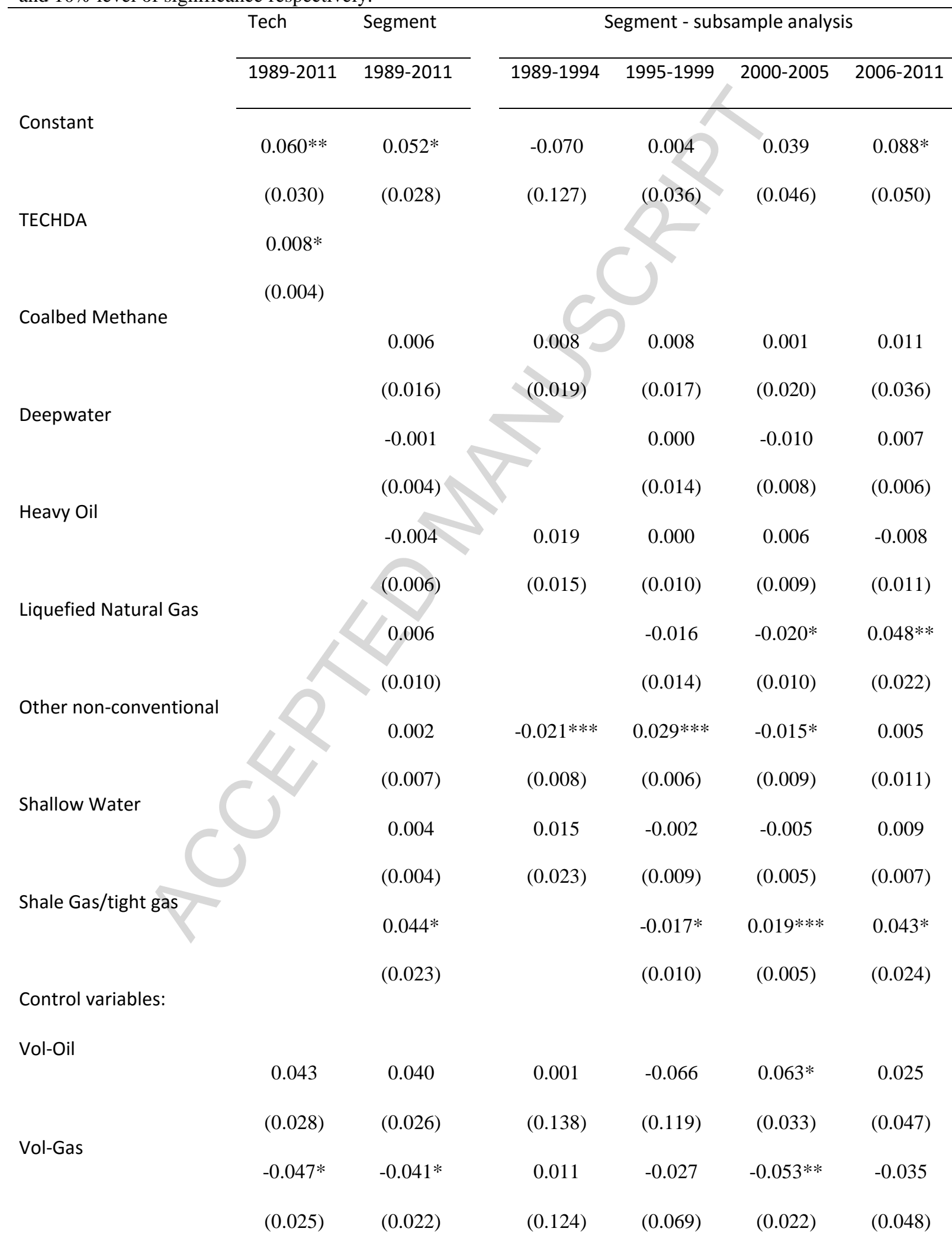




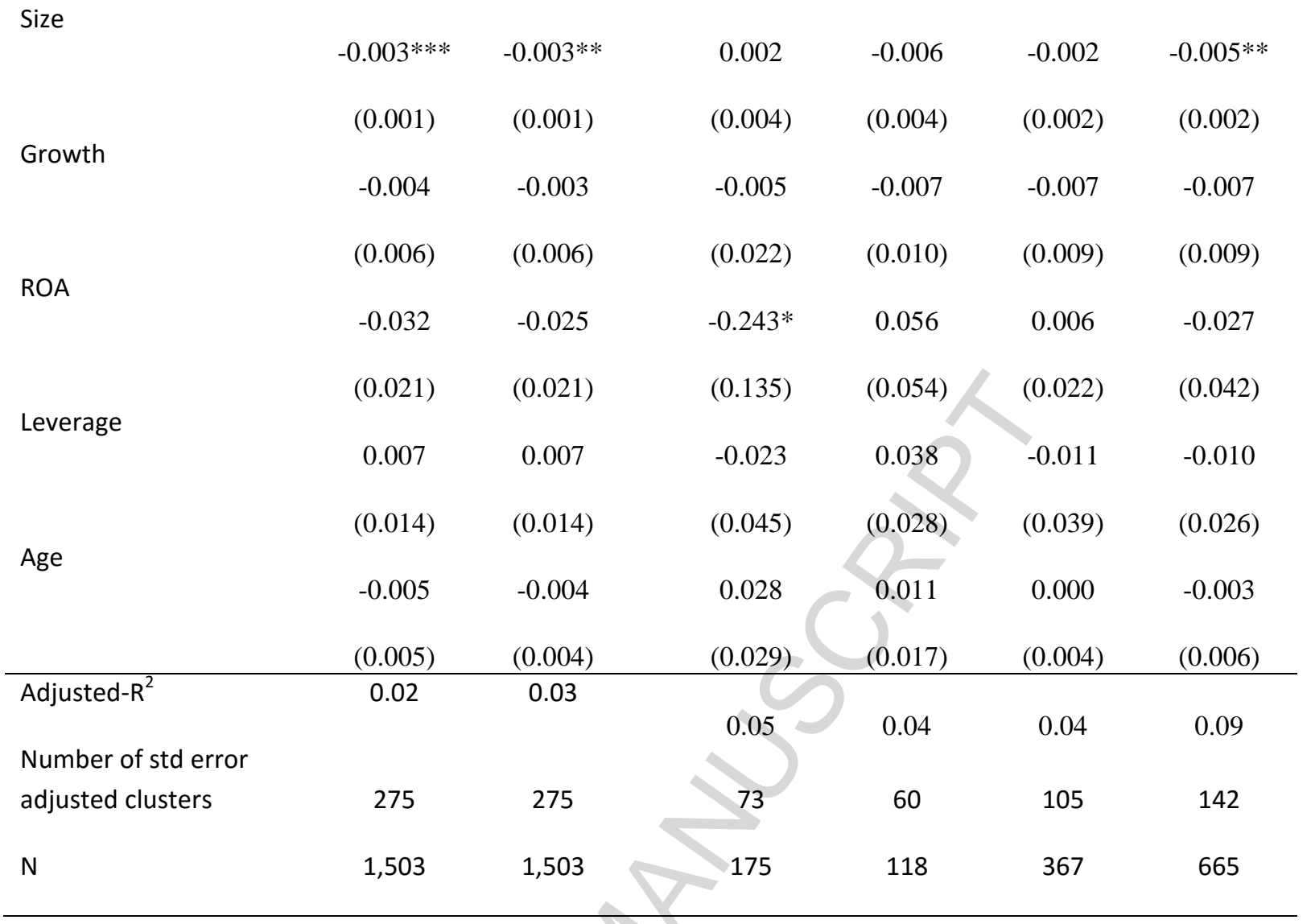




\section{Table 10: Acquisition and divestiture of shale gas}

This table reports market response to acquisition and divestiture announcements of shale gas. The parameters of expected return in Panel A and B are calculated over days -269 to -11, where day 0 is the announcement date. In Panel A, the parameters of expected return are calculated using Fama French Carhart four factor model. The market model is used to estimate the parameters of expected return in Panel B. The abnormal return in Panel C is calculated by subtracting the CRSP value weighted market index from the firm observed return over the event window. For average CARs, t-statistics are calculated using standardized cross-sectional method of Boehmer et al. (1991). The $* * *, * *$ and $*$ refer to $1 \%, 5 \%$ and $10 \%$ level of significance respectively.

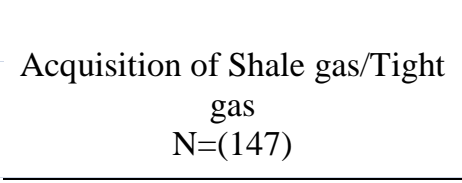

(1)
Difference

Divesting of shale gas/tight

gas

(N=74)

$(2)$

\begin{tabular}{|c|c|c|c|c|c|c|}
\hline Event Window & Mean CAR & t-stat & Mean CAR & t-stat & (1)-(2) & t-stat \\
\hline \multicolumn{7}{|c|}{ Panel A: Fama-French-Carhart four-factor model adjusted abnormal return. } \\
\hline$(-10,+10)$ & 0.0142 & 0.68 & 0.0602 & $2.65 * * *$ & -0.0460 & -1.61 \\
\hline$(-5,+5)$ & 0.0106 & 0.44 & 0.0636 & $3.52 * * *$ & -0.0530 & $-1.94 *$ \\
\hline$(-5,+1)$ & 0.0129 & 1.44 & 0.0633 & $3.97 * * *$ & -0.0503 & $-1.93^{*}$ \\
\hline$(0,0)$ & 0.0132 & $2.47 * *$ & 0.0283 & $2.68 * * *$ & -0.0152 & -1.10 \\
\hline$(-1,+1)$ & 0.0152 & $2.29 * *$ & 0.0544 & $3.57 * * *$ & -0.0392 & -1.56 \\
\hline$(0,+1)$ & 0.0135 & $2.17 * *$ & 0.0461 & $3.43 * * *$ & -0.0326 & -1.47 \\
\hline$(-1,+5)$ & 0.0128 & 0 & 0.0547 & $2.86 * * *$ & -0.0418 & -1.58 \\
\hline$(1,+10)$ & 0.0007 & -0.46 & 0.0034 & 0.27 & -0.0027 & -0.18 \\
\hline \multicolumn{7}{|c|}{ Panel B: Market model. } \\
\hline$(-10,+10)$ & 0.0111 & 0.73 & 0.0602 & $2.87 * * *$ & -0.0490 & -1.63 \\
\hline$(-5,+5)$ & 0.0102 & 0.71 & 0.0645 & $3.48 * * *$ & -0.0543 & $-1.93^{*}$ \\
\hline$(-5,+1)$ & 0.0112 & 1.55 & 0.0605 & $3.89 * * *$ & -0.0493 & $-1.88^{*}$ \\
\hline$(0,0)$ & 0.0132 & $2.47 * *$ & 0.0266 & $2.39 * *$ & -0.0133 & -0.98 \\
\hline$(-1,+1)$ & 0.0126 & $1.90 *$ & 0.0508 & $3.26^{* *}$ & -0.0382 & -1.54 \\
\hline$(0,+1)$ & 0.0121 & $1.96 *$ & 0.0430 & $3.12 * * *$ & -0.0309 & -1.42 \\
\hline$(-1,+5)$ & 0.0115 & 0.80 & 0.0547 & $2.81 * * *$ & -0.0432 & 1.62 \\
\hline$(1,+10)$ & -0.0017 & -0.67 & 0.0061 & 0.57 & -0.0078 & -0.52 \\
\hline \multicolumn{7}{|c|}{ Panel C: Zero-one market model. } \\
\hline$(-10,+10)$ & 0.0272 & $2.25 * *$ & 0.0672 & $3.57 * * *$ & -0.0400 & -1.45 \\
\hline$(-5,+5)$ & 0.0197 & $1.86^{*}$ & 0.0676 & $4.01 * * *$ & -0.0479 & $-1.81^{*}$ \\
\hline$(-5,+1)$ & 0.0170 & $2.43 * *$ & 0.0617 & $4.35 * * *$ & -0.0446 & $-1.78 *$ \\
\hline$(0,0)$ & 0.0135 & $2.57 * *$ & 0.0268 & $2.46 * *$ & -0.0133 & -0.99 \\
\hline$(-1,+1)$ & 0.0149 & $2.38 * *$ & 0.0504 & $3.39 * * *$ & -0.0355 & -1.47 \\
\hline
\end{tabular}




\begin{tabular}{lllllll}
$(0,+1)$ & 0.0122 & $2.09 * *$ & 0.0420 & $3.02 * * *$ & -0.0297 & -1.38 \\
$(-1,+5)$ & 0.0176 & $1.66^{*}$ & 0.0563 & $3.06^{* * *}$ & -0.0387 & -1.51 \\
$(1,+10)$ & 0.0045 & 0.49 & 0.0063 & 0.70 & -0.0018 & -0.12 \\
\hline
\end{tabular}




\section{Table 11: Portfolio analysis}

This table presents the univariate analysis. (Conv) refers to the portfolio of firms which invested in conventional resources. (Unconv) refers to the portfolio of firms which invested in unconventional resources. (MIX) refers to the portfolio of firms which invested in both conventional and unconventional resources. Panel $\mathrm{A}$ is estimated using a Buy and Hold return and Panel B is estimated using market adjusted return. The $\mathrm{t}$-test for differences in mean is estimated assuming unequal variances. The ${ }^{* * *}, * *$ and $*$ refer to $1 \%, 5 \%$ and $10 \%$ level of significance respectively.

\begin{tabular}{|c|c|c|c|c|c|c|c|c|c|c|c|c|c|c|c|}
\hline \multicolumn{10}{|c|}{ Panel A: Average Buy and Hold Return } & \multicolumn{2}{|c|}{ Mean difference } & \multicolumn{2}{|c|}{ Mean difference } & \multicolumn{2}{|c|}{ Mean difference } \\
\hline Period & $\mathrm{N}$ & $\operatorname{MIX}(1)$ & $\mathrm{t}$ & $\mathrm{N}$ & Conv (2) & $\mathrm{t}$ & $\mathrm{N}$ & Unconv (3) & $\mathrm{t}$ & $(1)-(2)$ & $\mathrm{t}$ & (1)-(3) & $\mathrm{t}$ & (2)-(3) & $\mathrm{t}$ \\
\hline$[0,12]$ & 1054 & $0.1504 * * *$ & 10.43 & 153 & $0.3375^{* * *}$ & 5.06 & 32 & $0.2123^{* *}$ & 2.18 & $-0.1871 * * *$ & -2.73 & -0.0619 & -0.62 & 0.1252 & 1.05 \\
\hline$[0,24]$ & 960 & $0.3043 * * * *$ & 12.60 & 132 & $0.7016^{* * *}$ & 3.93 & 29 & $0.3408^{* *}$ & 2.28 & $-0.3973 * *$ & -2.20 & -0.0365 & -0.24 & 0.3608 & 1.54 \\
\hline$[0,36]$ & 838 & $0.5722 * * *$ & 6.42 & 103 & $0.6720 * * *$ & 3.67 & 19 & $0.6680 *$ & 1.65 & -0.0998 & 0.49 & -0.0958 & -0.23 & 0.004 & 0.01 \\
\hline \multicolumn{16}{|c|}{ Panel B: Average Market adjusted Buy and Hold Return } \\
\hline Period & $N$ & MIX (1) & $\mathrm{t}$ & $N$ & Conv (2) & & $N$ & Unconv (3) & $\mathrm{t}$ & (1)-(2) & $\mathrm{t}$ & (1)-(3) & $\mathrm{t}$ & (2)-(3) & $\mathrm{t}$ \\
\hline$[0,12]$ & 1054 & $0.0842 * * *$ & 6.30 & 153 & $0.2102 * * *$ & 3.19 & 32 & 0.1032 & 1.24 & $-0.126 *$ & -1.87 & -0.019 & -0.22 & 0.1070 & 1.00 \\
\hline$[0,24]$ & 960 & $0.1421 * * *$ & 6.21 & 132 & $0.4302 * *$ & 2.43 & 29 & 0.1303 & 1.02 & -0.2881 & -1.61 & 0.0118 & 0.09 & 0.2999 & 1.37 \\
\hline$[0,36]$ & 838 & $0.3272 * * *$ & 3.68 & 103 & 0.2430 & 1.29 & 19 & 0.4017 & 1.08 & 0.0842 & 0.04 & -0.0745 & -0.19 & -0.1587 & 0.38 \\
\hline CAAR-FF & 1080 & $0.0070 * * *$ & 4.38 & 167 & 0.0087 & 1.51 & 35 & 0.0253 & 1.22 & -0.0017 & -0.27 & -0.0183 & -0.87 & -0.0166 & 0.77 \\
\hline
\end{tabular}


Figure 1: The fluctuation of natural gas prices and quantity of horizontal drilling in the U.S

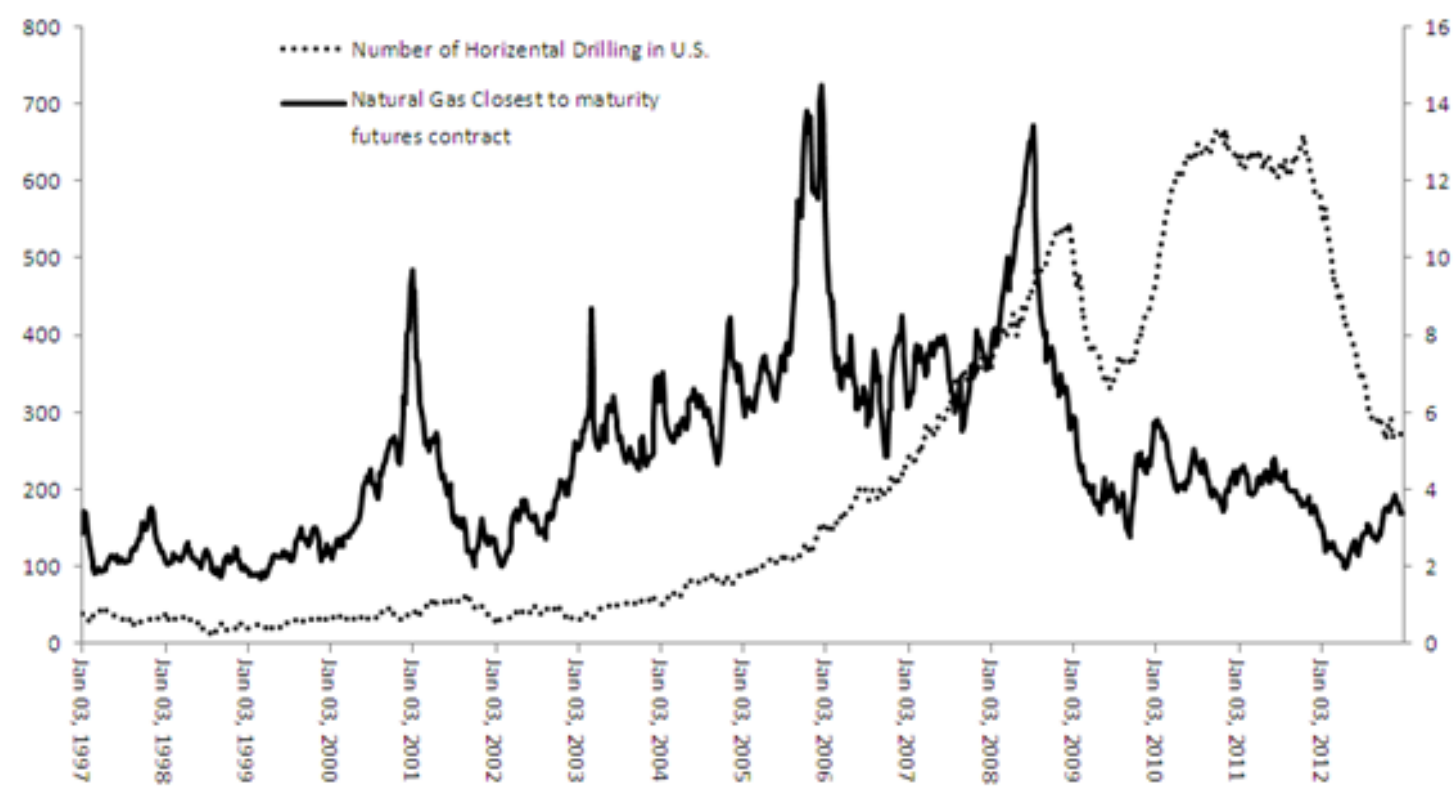

Source: EIA and smith bits Schelumberger. 
Figure 2: The number of news articles published in the WSJ about unconventional resources (1988-2011)

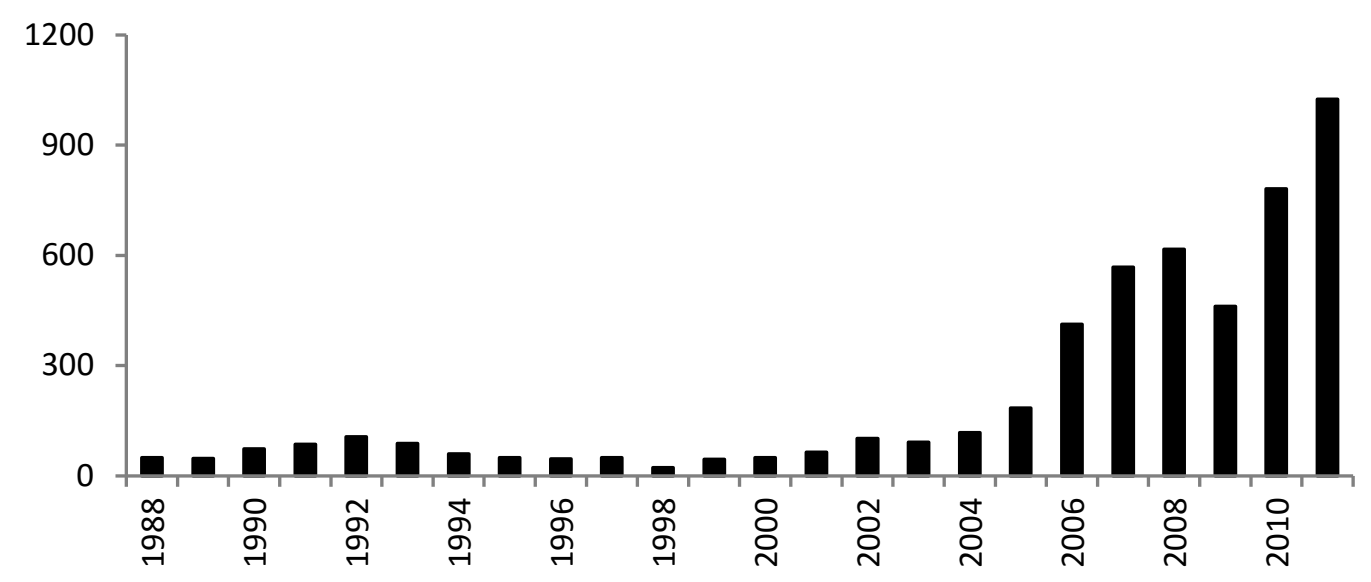




\section{Highlights}

- Investigation of the market response to specific oil and gas acquisition announcements

- Provides a test of how the equity market views the purchase of high tech unconventional resources by oil and gas firms

- Asset acquisitions tend to increase equity value on average, consistent with information asymmetry arguments.

- Positive wealth effects are observed for both acquirer and seller of conventional resources.

- On average, both the seller and buyer benefit from these resource transactions. 